\title{
Do protagonismo à invisibilidade: Geografia Histórica do córrego do Acaba Mundo e a sua relação com o sítio de Belo Horizonte-MG (1716/1973)
}

\author{
From protagonism to invisibility: Historical Geography of Acaba Mundo Stream \\ and its relationship with the Belo Horizonte - MG (1716/1973)
}

\begin{abstract}
Alessandro Borsagli
Mestre em Geografia pelo Programa de Pós-Graduação em Geografia/Tratamento da Informação Espacial (PPGG-TIE) da Pontifícia Universidade Católica de Minas Gerais, Brasil

borsagli@gmail.com
\end{abstract}

José Flávio Morais Castro

Doutor em Geografia, Prof. Adjunto IV do Programa de Pós-Graduação em Geografia/Tratamento da Informação Espacial (PPGG-TIE) da Pontifícia Universidade Católica de Minas Gerais, Brasil

joseflavio@pucminas.br

\begin{abstract}
Resumo
O artigo tem como objetivo analisar a relação do córrego do Acaba Mundo com o sítio ocupado pela cidade de Belo Horizonte. Correndo atualmente sob diversas vias da região centro-sul da capital mineira, o curso d'água possui grande importância não só para os estudos sobre a ocupação do sítio do arraial do Curral del Rey, mas também para a reconstrução das paisagens profundamente modificadas a partir do processo de evolução urbana de Belo Horizonte, onde a geografia histórica se encontra intrinsecamente ligada à paisagem. A abordagem da pesquisa foi trabalhada através da Geografia Histórica, possibilitando dessa forma a realização de uma contextualização geohistórica da ocupação do sítio que veio a receber a nova capital de Minas Gerais. Nesse contexto, observa-se que o curso d'água foi de grande importância para o abastecimento e para a forma do arraial, perdendo gradativamente importância ao longo do processo de evolução urbana de Belo Horizonte.
\end{abstract}

Palavras-chave: Belo Horizonte; Rede Hidrográfica; Geografia Histórica; Córrego do Acaba Mundo.

\begin{abstract}
This article aims to analyze the relationship of the Acaba Mundo stream with the site occupied by Belo Horizonte. Currently running under various routes in the centre-south region of the capital of Minas Gerais, this stream features great importance for studies about the site of the Curral del Rey occupation. Moreover, it is also important to reconstruct deeply modified landscapes from the urban evolution process of Belo Horizonte, where historical geography is intrinsically linked to the landscape. The research approach was worked through the Historical Geography, thus enabling the realization of a geohistorical contextualization of the site occupation that came to receive the new capital of Minas Gerais. In this context, it is observed that the watercourse was of great importance for the supply and the shape of the village, gradually losing importance throughout the process of urban evolution of Belo Horizonte.
\end{abstract}

Keywords: Belo Horizonte; Hydrographic Network; Historical Geography; Acaba Mundo Stream. 


\section{INTRODUÇÃO}

A sociedade e os cursos d'água mantém uma relação bastante antiga. Desde tempos imemoriais, os núcleos urbanos se estabelecem às margens dos cursos d'água, inclusive as cidades localizadas à beira mar (COSTA, 2006). No Brasil a ocupação ocorreu de forma semelhante, ou seja, no litoral e às margens dos cursos d'água. Estabelecidas inicialmente à beira mar, na medida em que se penetrava para dentro do território, as cidades eram fundadas ao longo dos caminhos abertos pelos desbravadores, geralmente às margens de cursos d'água de grande, médio ou pequeno porte (COSTA, 2006), ou nas vertentes abruptas das águas que encerravam grandes depósitos auríferos cobiçados pela metrópole portuguesa e pelos seus ávidos súditos (ESCHWEGE,1979).

A água, além de fornecer condições para a sobrevivência dos núcleos urbanos, também fornecia riquezas e possibilidade de conexão entre os povoados e vilas, incrementando o comércio e contribuindo para o controle do território. Além disso, o tecido urbano de uma cidade geralmente se desenvolve a partir do eixo de um curso d'água, que em alguns casos determina e norteia o seu crescimento. A água é uma das garantias da sobrevivência de um núcleo urbano.

No sítio ocupado atualmente pela cidade de Belo Horizonte, a rede hidrográfica foi fator determinante para a ocupação do território, uma vez que o arraial do Curral del Rey, povoado fundado no primeiro quartel do século XVIII e desaparecido a partir da construção da nova capital de Minas Gerais (1894/1897), ocupava uma parte das vertentes do córrego do Acaba Mundo, próximo à confluência com o ribeirão Arrudas. Nesse contexto o Acaba Mundo foi, por quase duzentos anos, de grande importância não só para a morfologia do arraial, que se expandiu em parte de suas vertentes, mas também para o abastecimento de água e para as pequenas indústrias, estabelecidas em sua bacia (MINAS GERAES, 1893).

No entanto, a partir do ano de 1894 com a chegada da Comissão Construtora da Nova Capital (CCNC) ao arraial de Belo Horizonte, antigo Curral del Rey, uma vez que o seu sítio havia sido escolhido para sediar o novo centro administrativo do Estado, o córrego do Acaba Mundo foi gradativamente perdendo importância como elemento integrador e de referência na paisagem, dentro dos preceitos racionais e higienistas do século XIX que promoveram significativa alteração na relação entre os centros urbanos e os elementos naturais (BORSAGLI, 2016). Dentro dos planos da CCNC o Acaba Mundo, assim como os demais cursos d'água que se encontram dentro do perímetro estabelecido para a nova capital, passou a ser considerado um elemento que não permitia a evolução urbana de maneira regular, desaparecendo da paisagem urbana ao longo do século XX.

Nesse sentido o artigo tem como objetivo analisar, a partir da perspectiva geográficahistórica, a relação do córrego do Acaba Mundo com o sítio ocupado pela cidade de Belo Horizonte. Correndo atualmente sob diversas vias da região centro-sul da capital mineira, o curso d'água possui 
grande importância não só para os estudos sobre a ocupação do sítio do arraial do Curral del Rey, mas também para a reconstrução das paisagens profundamente modificadas a partir do processo de evolução urbana de Belo Horizonte, onde a geografia histórica se encontra intrinsecamente ligada à paisagem, modificada e adaptada a partir das necessidades e interesses da sociedade.

A relação cidade/rio é um tema que vem sendo abordado por diversos pesquisadores nos últimos anos em diferentes áreas do conhecimento. Nesse contexto, grande parte dos trabalhos abordam a reabilitação dos cursos d'água em meio urbano ou a inserção urbano-paisagístico de um determinado curso d'água que corre sob um determinado centro urbano, entre outros trabalhos que comprovam a importância da rede hidrográfica para a cidade.

Muitos trabalhos relacionados aos cursos d'água possuem abordagem geográfica, histórica, ambiental, cultural, social e econômica, visto que a rede hidrográfica é um importante elemento de referência na paisagem. No entanto, em Belo Horizonte, até o presente momento, não se não se estabeleceu uma relação entre o sítio do arraial de Belo Horizonte e o córrego do Acaba Mundo, assim como os diferentes "protagonismos" que o curso d'água teve entre os anos de 1897 e 1965 (BORSAGLI, 2016).

Nesse sentido é importante analisar, sob o olhar geográfico-histórico, as relações entre a evolução do tecido urbano surgido sobre o sítio de Belo Horizonte nos períodos colonial, imperial e republicano, uma vez que a morfologia de grande parte dos centros urbanos do ocidente possui notável relação com o rio (CASTONGUAY e EVENDEN 2010), muitas vezes responsável pelo desenho da cidade e pela maneira de ocupação do território.

\subsection{Contextualização do Córrego do Acaba Mundo}

Para que se possa compreender a importância do córrego do Acaba Mundo para o povoamento do sítio atualmente ocupado por parte da cidade de Belo Horizonte e todo o processo de invisibilidade do curso d'água, se faz necessária a breve localização e descrição do córrego do Acaba Mundo baseada em Borsagli (2016) e a análise sobre os conceitos de Geografia Histórica abordados por Sauer (1941), Abreu (2000 e 2008), Silva (2012) e Erthal (2003) e os conceitos de sítio e posição geográfica, abordados por Ab'Saber (1957), Geiger \& Davidovich (1961), George (1983) e Corrêa (2004).

Assim como grande parte dos afluentes da margem sul do ribeirão Arrudas, o córrego do Acaba Mundo tem as suas nascentes localizadas nas vertentes da Serra do Curral, em local atualmente explorado pela Mineração Lagoa Seca, possuindo cerca de seis quilômetros de extensão. Desde sua nascente até o início do canal coberto, o curso d'água percorre cerca de 1500 metros em canal aberto, seguindo em canal fechado pelas Avenidas Uruguai e Nossa Senhora do Carmo, pelas Ruas Outono, 
Grão Mogol, Professor Morais e Avenida Afonso Pena, desaguando no ribeirão Arrudas próximo ao Parque Municipal. Seus afluentes são os Córregos Ilha (Ruas Assunção e Venezuela) e Gentio (Avenida Francisco Deslandes, Ruas Odilon Braga, Vitorio Marçola e Outono).

A sua microbacia se encontra inserida na região centro-sul de Belo Horizonte e apresenta alto grau de urbanização, ao mesmo tempo em que o curso d'água se encontra em leito natural no trecho correspondente às cabeceiras e a Vila Acaba Mundo. É importante ressaltar que o curso d'água possuía treze nascentes notáveis em suas cabeceiras (CCNC, 1895), sendo atualmente conhecidas e consideradas cinco nascentes notáveis, todas localizadas dentro da área da Mineração Lagoa Seca.

\subsection{Geografia Histórica}

A geografia histórica pode ser definida como um ramo da geografia que estuda o presente que existiu em algum momento do que hoje é o passado (SILVA, 2012), onde a concentração e atuação de um determinado grupo em uma determinada área geram formas e deixam marcas na paisagem, adaptada e modificada a partir de suas necessidades e interesses.

Para Sauer (1941) e Abreu (2000), a geografia histórica trabalha com os fragmentos deixados pelo passado, não deixando de considerar que os documentos não são neutros, ou seja, que incorporam estruturas de poder, ao mesmo tempo em que existem fatos não registrados. Erthal (2003) acrescenta ainda que, na tradição clássica, a geografia histórica contribuiu significativamente para a contextualização geográfica de inúmeros países, ao tratar de temas relacionados à paisagem e à região, expressando-se diversas vezes a partir da cartografia. No entanto, a geografia clássica não apresenta um desenvolvimento linear como as demais geográficas, de acordo com Silva (2008), que aponta períodos de pleno reconhecimento e períodos de não reconhecimento, a partir da premissa informal que a geografia deve tratar apenas do presente, relegando à história o estudo de qualquer fenômeno relacionado ao passado.

Sauer (1941) observa ainda que o geografo histórico deve ser um especialista regional, pois a ele cabe o papel de reconhecer não só a região na atualidade, mas também os traços, ou marcas na paisagem que permita uma reconstituição do passado, buscando inclusive ver a terra com os olhos dos seus antigos habitantes.

Belo Horizonte é uma cidade que apresenta em sua paisagem urbana inúmeros traços, em grande parte arquitetônicos, que permitem uma análise paisagística de um passado não tão distante, ainda que a rápida transformação espacial ocorrido em um espaço de tempo relativamente curto a partir da premissa da busca pela modernidade (BORSAGLI, 2016), apagou da paisagem urbana diversas formas e marcas de uma sociedade oriunda do meio rural. No caso dos elementos naturais, a reconstrução paisagística é ainda mais complexa, visto que as grandes movimentações de terra, 
terraplanagens e intervenções na rede hidrográfica alteraram de maneira significativa o sítio anteriormente ocupado pelo arraial de Belo Horizonte, antigo Curral del Rey (Figura 1).

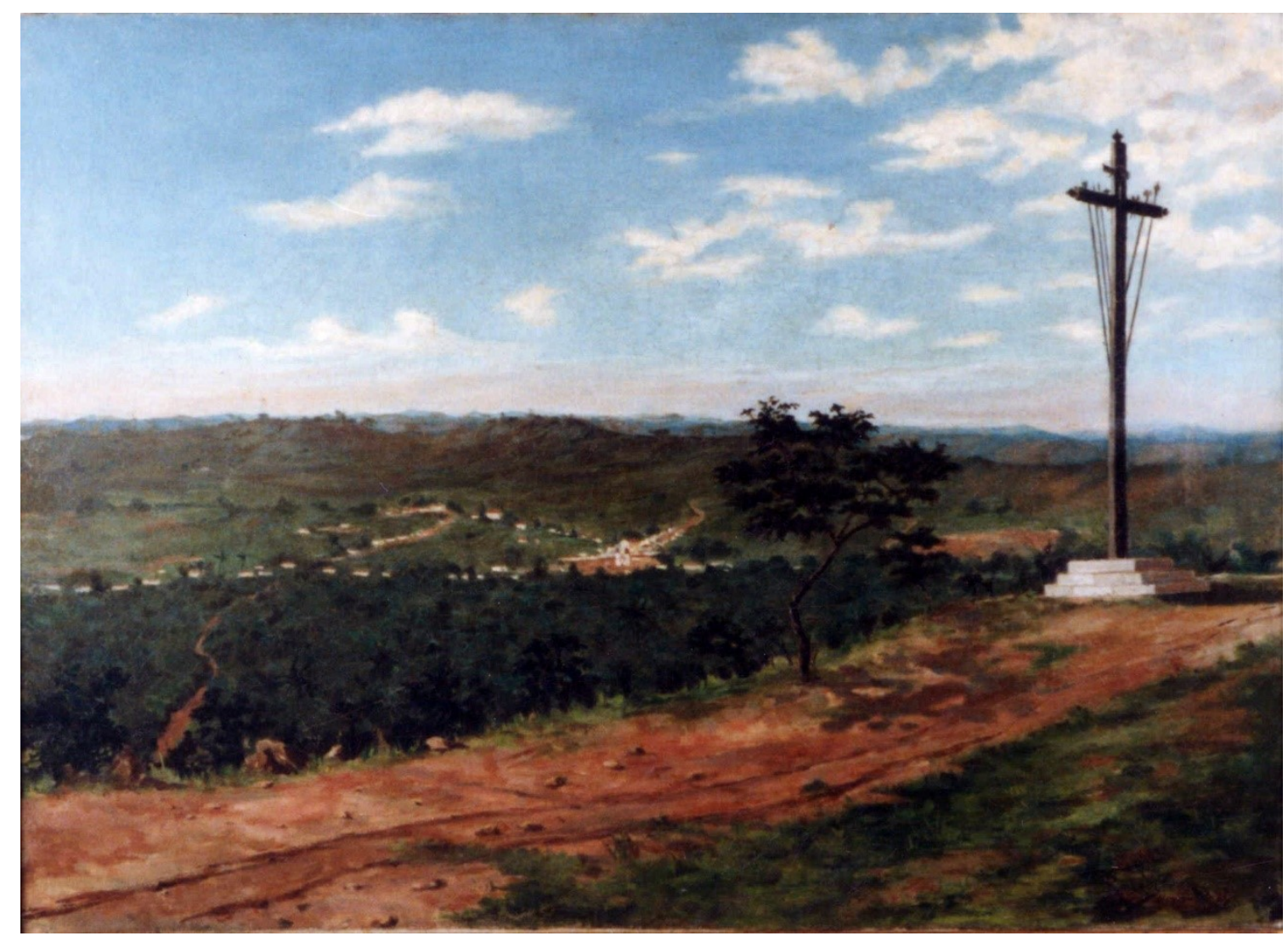

Figura 1 - Perspectiva na direção N do arraial de Belo Horizonte no ano de 1894 a partir do Morro do Cruzeiro, interflúvio dos córregos do Acaba Mundo e Serra.

Fonte: Pintura de Émile Rouède - Museu Histórico Abílio Barreto acervo CCNC.

\subsection{Sítio e Posição Geográfica}

Para Ab’Saber (1957) o sítio urbano pode ser considerado um pequeno quadro de relevo que efetivamente aloja um organismo urbano. O sítio, de acordo com Dollfus (1973), é o assentamento territorial de um elemento do espaço. Nesse sentido, o sítio de uma cidade pode ser entendido como o conjunto de elementos físicos e naturais que possibilitam o assentamento humano e posterior modificação de acordo com as necessidades da sociedade.

Corrêa (2004) observa que a localização de uma cidade envolve duas escalas espaciais, a localização absoluta (sítio) e a localização relativa (posição), na qual o sítio é o chão sobre o qual a cidade se estende, podendo ser natural ou artificialmente produzido. Compreende-se que a localização das cidades não ocorre de forma aleatória, envolvendo inúmeras ações que antecedem a escolha do sítio ideal para a ocupação humana, além da necessidade de existência de recursos naturais, acessibilidade, produção de víveres e possibilidade de comunicação com outros assentamentos humanos. 
Nesse sentido, a posição geográfica de uma cidade pode ser entendida como a sua localização em relação aos fatores naturais que possam proporcionar o seu desenvolvimento ao longo do tempo (CORRÊA, 2004). O clima, o relevo, a existência de recursos minerais e a existência de solos para a agricultura são fatores relevantes para o desenvolvimento de um núcleo urbano. Para Geiger \& Davidovich (1961), o fator posição, juntamente com o fator sítio, representa o aspecto geográfico do estudo urbano, cabendo o papel mais importante do desenvolvimento das cidades.

É importante observar que os estudos realizados pelos autores foram realizados em um momento em que a metropolização e o surgimento de aglomerações urbanas era uma realidade no cenário urbano do Brasil, no entanto os mesmos observam que o critério de origem não poderia ser utilizado para estabelecer uma classificação de cidade, pois considera apenas um período de evolução dos centros urbanos. A ideia de construção de um novo centro administrativo estadual surgiu exatamente da estagnação da antiga capital (Ouro Preto), que não apresentava condições de expansão urbana devido ao seu sítio acidentado (NATAL, 2007).

Nesse contexto, Geiger e Davidovich (1961) sugerem uma classificação dos tipos de cidades a partir de uma combinação entre o tipo de centro de relação e de centro industrial, ressaltando que o modelo surgiu a partir de um estágio de desenvolvimento que se encontravam os centros urbanos brasileiros no ano de 1950. No caso abordado, o que interessa é a importância da posição de uma cidade e o sítio na qual se encontra assentada.

Para George (1983), a posição pode ser definida como a localização da cidade em função de fatos naturais susceptíveis, no passado ou no presente, de influir em seu desenvolvimento que, por sua vez, está vinculado à facilidade de expansão. Ao aplicar o conceito no caso de Belo Horizonte, observa-se que a urbe foi construída de maneira a permitir sua expansão para os vetores norte, leste e oeste, tendo como barreira natural o Complexo da Serra do Curral.

A localização de uma cidade pode ser crucial em alguns períodos históricos, ao mesmo tempo em que perde importância a partir das transformações econômicas e sociais, como observado por Corrêa (2004), no período da Revolução Industrial, quando os centros urbanos sofreram transformações nunca vistas até então.

Corrêa (2004) realizou uma divisão dos tipos de posições ideais das cidades, ressaltando as características principais de cada tipologia. As posições estão alinhadas com as questões físicas da região, assim como as condicionantes de transporte, como linhas férreas e rodovias de grande fluxo, modais que contribuíram de forma notável para a alteração geográfica de cidades, que possuíam ou não certa importância regional e mesmo interestadual a partir do encurtamento do tempo de comunicação entre as cidades, ao mesmo tempo em que outras permaneceram ligadas pelas antigas estradas. 
Nesse sentido, para o Estado, a posição geográfica da nova capital era de grande relevância para a irradiação da influência que seria exercida por ela. Ou seja, a posição geográfica do arraial de Belo Horizonte foi fator crucial para a escolha do sítio que abrigou a nova capital do Estado e as adaptações realizadas de acordo com as necessidades sociais, econômicas e institucionais. Observase ainda que o sitio escolhido se encontrava em posição geográfica favorável, situado entre os vales dos rios das Velhas e Paraopeba, próximo às duas principais linhas férreas do Estado (1893). Ressaltase que a abertura do ramal ferroviário da Estrada de Ferro Central do Brasil (E.F.C.B.) ocorrida no ano de 1895, e a conexão com a linha tronco da Estrada de Ferro Oeste de Minas (EFOM) contribuiu para que Belo Horizonte se tornasse no século XX um dos principais entrepostos ferroviários da Região Sudeste, abrigando ainda as principais oficinas de construção e manutenção de locomotivas da E.F.C.B, observando que o vale do ribeirão Arrudas tornou-se o eixo de ligação entre a cidade e a infraestrutura ferroviária.

Enfim, o sítio e a posição geográfica proporcionariam o desenvolvimento de cidades a partir de condicionantes geográficas favoráveis.

\section{ACABA MUNDO, ARRAIAL DO CURRAL DEL REY E BELO HORIZONTE}

\subsection{O arraial, córrego do Acaba Mundo e a construção da nova capital (1716/1897)}

O arraial do Curral del Rey foi edificado na região central do Estado de Minas Gerais, na bacia do rio das Velhas, em um sítio que apresenta uma altitude média de 876 metros do nível do mar (BARRETO, 1936) e que se encontra localizado na Depressão Periférica de Belo Horizonte, no contato com a Serra do Curral del Rey na direção sul. Na direção norte o arraial se limitava com a Serra da Contagem ou Serra da Onça, divisor das bacias hidrográficas dos ribeirões Arrudas e Onça, ambos afluentes da vertente oeste do rio das Velhas.

O sitio onde se edificou o arraial se encontra próximo a borda norte do Quadrilátero Ferrífero, assentado sobre as bacias dos córregos da Serra, Acaba Mundo e Leitão, todos com suas nascentes localizadas na Serra do Curral, correspondente à vertente sul do ribeirão do Curral (ribeirão Arrudas), principal curso d'água do arraial. Na porção norte destacam-se três cursos d'água provenientes da Serra da Onça/Contagem (córregos do Pastinho, Lagoinha e Mata), afluentes da vertente norte do Arrudas.

No que tange às vias de comunicação, a estrada das Minas via Congonhas de Sabará era o principal eixo de conexão entre o Curral del Rey e os povoados da região aurífera inserida nos domínios do Quadrilátero Ferrífero, onde a demanda por víveres era alta devido à grande concentração populacional nos séculos XVIII e XIX (GONÇALVES, 2016). 
A estrada para Sabará era uma outra opção para se chegar às minas, ainda que aumentasse o tempo de viagem devido ao contorno da Serra do Curral, visto que a estrada seguia pelos vales do ribeirão Arrudas e rio das Velhas. A estrada para Venda Nova seguia na direção oposta aos demais caminhos na ponte do Sacco, divisa do arraial e a Vargem da Lagoinha, esta última localizada entre a Serra da Onça e o ribeirão Arrudas. Era a principal rota de ligação entre o arraial e o norte de Minas Gerais.

O arraial se apresentava em formato de T (MINAS GERAES, 1893), resultado da confluência de três importantes estradas que remetem ao período colonial: ao norte a estrada de Venda Nova (estrada dos Currais), ao sul a estrada das Congonhas (estrada das Minas) e a leste a estrada de Sabará (Figura 2). De acordo com Vaz de Melo, Cerqueira e Vieira (BARRETO, 1936) o terreno ocupado pelo arraial estendia-se por um quilometro no sentido leste/oeste e por dois quilômetros no sentido norte/sul, possuindo duas igrejas católicas e os seus respectivos largos, dos quais iniciavamse as ruas do povoado.

O arraial se caracterizava pela irregularidade característica dos núcleos urbanos surgidos no período colonial, onde grande parte das vilas e dos povoados mineiros apresentam uma morfologia que acompanham quase sempre as estradas e a topografia (DEFFONTAINES, 1938), ao mesmo tempo em que as edificações eram geralmente locadas de modo a ocultar nos fundos dos terrenos a rede hidrográfica, aos quais eram legados o transporte dos esgotos e detritos gerados nas aglomerações humanas (BORSAGLI, 2016).

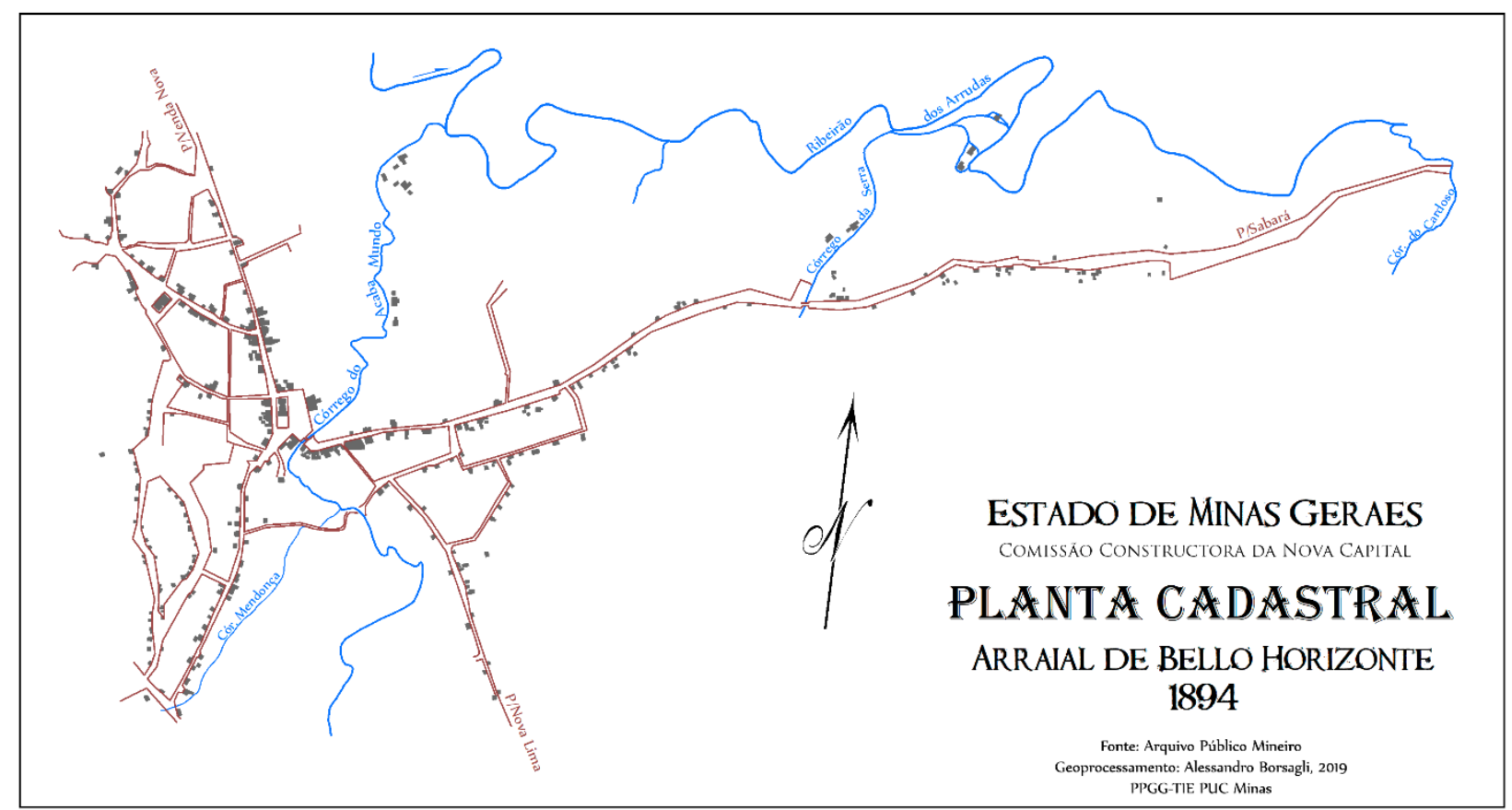

Figura 2 - Planta Cadastral do arraial de Belo Horizonte, 1894. Detalhe para o córrego do Acaba Mundo, dividindo o arraial em duas porções irregulares.

Fonte: Modificado de Arquivo Público Mineiro. 
Grande parte do arraial se encontrava na vertente oeste do córrego do Acaba Mundo, sendo que o interflúvio Acaba Mundo/Leitão era o limite da porção oeste do tecido urbano, ao mesmo tempo em que o córrego da Serra era o limite leste do arraial, ou seja, as três microbacias hidrográficas afluentes do ribeirão Arrudas, de alguma maneira eram responsáveis pelos limites do arraial, que permaneceu durante quase dois séculos concentrado próximo ao talvegue do Acaba Mundo.

É importante observar que até o presente momento não existem informações a respeito do córrego do Acaba Mundo durante o período compreendido entre os anos de 1716 e 1892, apenas referências à abundância de águas e fertilidade dos terrenos da Freguesia do Curral del Rey (MARTINS e OLIVEIRA, 1864) e aos relatos de Burton (2001) e Castelnau (1949), que realizam observações gerais a respeito do arraial, onde o elemento que mais se destacava era a Serra das Congonhas, ou Serra do Curral del Rey.

As primeiras informações mais detalhadas sobre o sítio do arraial de Belo Horizonte foram realizadas no ano de 1890 por Vaz de Melo, Cerqueira e Vieira (BARRETO, 1936), que elaboraram um estudo descritivo do sítio do arraial com finalidades de receber a nova capital, e no ano de 1893 a partir das pesquisas de campo realizadas pelo engenheiro Samuel Gomes Pereira, integrante da Comissão de Estudos das Localidades Indicadas para a Nova Capital, criada um ano antes para estudar as cinco localidades indicadas pelo Estado para receber a nova capital.

Entre as dez condicionantes analisadas pelo engenheiro, destacam-se as observações realizadas a respeito da posição geográfica, abastecimento, qualidade das águas e econômica, entre outras condicionantes onde o ribeirão do Acaba Mundo é regularmente citado (MINAS GERAES, 1893). A análise do sítio realizada a partir da rede hidrográfica ressalta a importância dos cursos d'água para a forma do arraial, em grande parte assentado sobre a vertente oeste do Acaba Mundo:

A povoação atual tem a forma de um $T$ em projeção horizontal. A alma, ou haste vertical do
$T$ representa a esplanada à margem direita elo Ribeirão dos Arrudas, com a extensão de 3
quilômetros e a declividade média de $0 \mathrm{~m}, 010$ no sentido longitudinal e com a largura média
de 600 metros e declividade $0 \mathrm{~m}, 020$ em sentido transversal. A mesa, ou travessão do $T$
representada pela projeção horizontal do plano inclinado formado pela encosta oriental do
espigão que separa o ribeirão do Acaba-Mundo, do córrego do Leitão, com a extensão de 2
quilômetros e a declividade média de $0 \mathrm{~m}, 015$ no sentido longitudinal e com a largura média
de 400 metros e a declividade máxima de $0 \mathrm{~m}, 070$ no sentido transversal (MINAS GERAES,
1893 , p.6).

Observa-se ainda que o engenheiro se referiu ao Acaba Mundo como ribeirão e não como um córrego, o que pode ser entendido pelo fato de ser o principal curso d'água do arraial, uma vez que o Largo da Matriz de Nossa Senhora da Boa Viagem e algumas das principais vias se localizavam próximos ao seu leito. O ribeirão Arrudas se encontrava a uma distância considerável do povoado e atravessava inúmeras propriedades rurais que se encontravam próximas às suas margens. Ou seja, possivelmente o Acaba Mundo foi denominado de ribeirão pela Comissão de Localidades por sua centralidade perante o arraial, ainda que não possuía nem comprimento e nem vazão para tal, ao 
mesmo tempo em que é afluente de um ribeirão que é conhecido como tal desde o período colonial (BARRETO, 1936).

O Acaba Mundo foi ainda analisado pela Comissão para fins de abastecimento da nova capital, uma vez que o curso d'água era responsável pelo abastecimento do arraial a partir de um aqueduto que captava as águas na cota 940, distribuindo-as de maneira irregular ao longo da vertente oeste do Acaba Mundo até desaguar o excedente no córrego do Leitão, próximo ao antigo Largo do Rosário (BORSAGLI, 2016).

Apesar da sua excelente qualidade, as águas do curso d'água foram logo descartadas pela Comissão Construtora da Nova Capital ao chegar ao arraial de Belo Horizonte no início de 1894. A baixa vazão registrada pela CCNC no período de estiagem (cerca de trinta e dois litros por segundo), foi considerada insuficiente para abastecer até mesmo um pequeno povoado (BARRETO, 1936), mesmo que suas águas fossem utilizadas para o abastecimento de uma porção do arraial.

A partir desse momento, tem-se o início de um rompimento de ordem urbano-paisagística, uma vez que os planos da CCNC para a nova capital não indicavam o estabelecimento de uma harmonia entre o meio natural e o ambiente construído, onde a negação das formas urbanas oriundas do período colonial ficou mais explicita a partir da apresentação da planta da nova capital, ocorrida no ano de 1895 (Figura 3).

A Planta Topográfica da Cidade de Minas contém a planta geral sobre parte da topografia do sítio escolhido, destacando-se os espaços destinados para a população urbana, suburbana e a região dos sítios, o relevo e a rede hidrográfica que atravessa a zona urbana planejada e adjacências.

Nota-se a discrepância entre a grade ortogonal e o traçado dos cursos d'água, ao mesmo tempo em que o ribeirão Arrudas, marco geográfico do sítio, figura como o único curso d'água inserido grade ortogonal como um elemento de referência na paisagem urbana. $\mathrm{O}$ traçado dos demais cursos d'água não apresentam harmonia com o racional planejado, um indício da desconsideração fluvial do sítio, em um momento em que os estudos de intervenção fluvial haviam sido apenas iniciados (BORSAGLI, 2016).

Nesse contexto o córrego do Acaba Mundo, até então de grande importância urbana, social e de abastecimento do arraial de Belo Horizonte, assumiu um novo protagonismo perante a nova ordem urbana, onde o liquido elemento, estendido para as demais microbacias inseridas dentro do limite estabelecido pela CCNC para a nova capital, passaria a ser controlado pela racionalidade técnica onde os planos políticos se sobressaíram em relação aos planos urbanísticos.

A partir desse momento, a racionalidade técnica foi imposta sobre o sítio, onde a grade ortogonal pode ser considerada como um plano que não se harmoniza com as formas de um relevo que deveria ser modificado a partir de preceitos que buscavam o controle sobre um ambiente que 
deveria ser adequado de acordo com os interesses e necessidades da sociedade, que a partir do saber técnico rompia de maneira profunda com o meio físico, com a paisagem e com a rede hidrográfica.

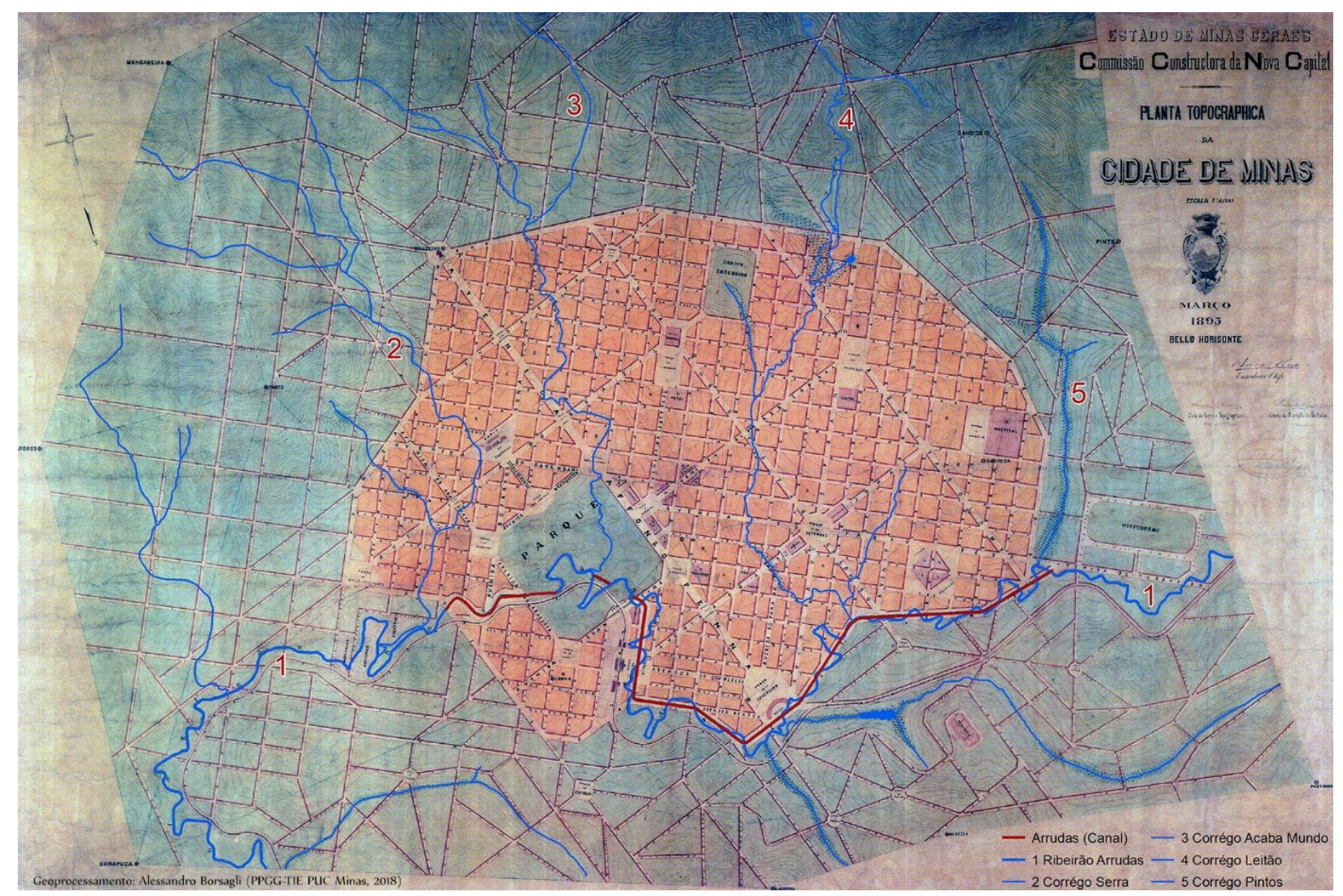

Figura 3 - Planta Topográfica da Cidade de Minas, 1895. Detalhe para o córrego do Acaba Mundo (3) e a incompatibilidade entre o seu traçado natural e a geometria da cidade planejada.

Fonte: modificado de Arquivo Público da Cidade de Belo Horizonte.

Entre os anos de 1896 e 1897 foram iniciados os estudos e as obras de retificação e canalização do córrego do Acaba Mundo, ao mesmo tempo em que suas águas foram capadas pela CCNC de maneira provisória, afim de atender a alta demanda de abastecimento dos operários que trabalhavam na construção da capital e dos moradores que ainda se encontravam no arraial em demolição.

De acordo com Penna (1997), o volume captado alimentava 15 chafarizes e 29 torneiras públicas, algumas oficinas e hotéis criados nas casas do arraial desapropriado. Nesse contexto, o Acaba Mundo tornou-se o primeiro curso d'água a ser captado, ainda que provisoriamente, para abastecer a nova capital e o primeiro a possuir um projeto de intervenção fluvial, um modelo que posteriormente seria aplicado nos demais cursos d'água que se encontravam dentro do perímetro da nova capital.

Segundo Barreto (1936), a partir de informações retiradas de um relatório descoberto por ele durante as pesquisas para a publicação do livro Belo Horizonte: Memória Histórica e Descritiva sobre as obras executadas no ano de 1897 , foram realizadas obras de escavação e alvenaria na Avenida 
Afonso Pena e Rua Paraibuna, com o intuito de canalização das águas do córrego do Acaba Mundo, em uma extensão total de trezentos e noventa e dois metros e quinhentos e cinquenta e quatro metros respectivamente. No entanto, observa-se que as obras foram interrompidas após a inauguração da capital, ocorrida em 12 de dezembro de 1897 e com a extinção da CCNC nos primeiros dias de 1898.

Nesse sentido é importante observar que, ainda que as obras de construção do canal haviam sido iniciadas no ano de 1897 (Figura 4), o mesmo não se encontrava apto a receber as águas do Acaba Mundo, que continuou a correr em seu leito natural até a década de 1920, quando se tem o início das grandes intervenções fluviais nos cursos d'água que atravessam a zona urbana planejada de Belo Horizonte, ressaltando que a realidade expressada em relatórios e documentos oficiais, em alguns casos, não expressa a realidade urbana de um determinado período, como observou Borsagli (2016), ao analisar as intervenções na rede hidrográfica de Belo Horizonte.

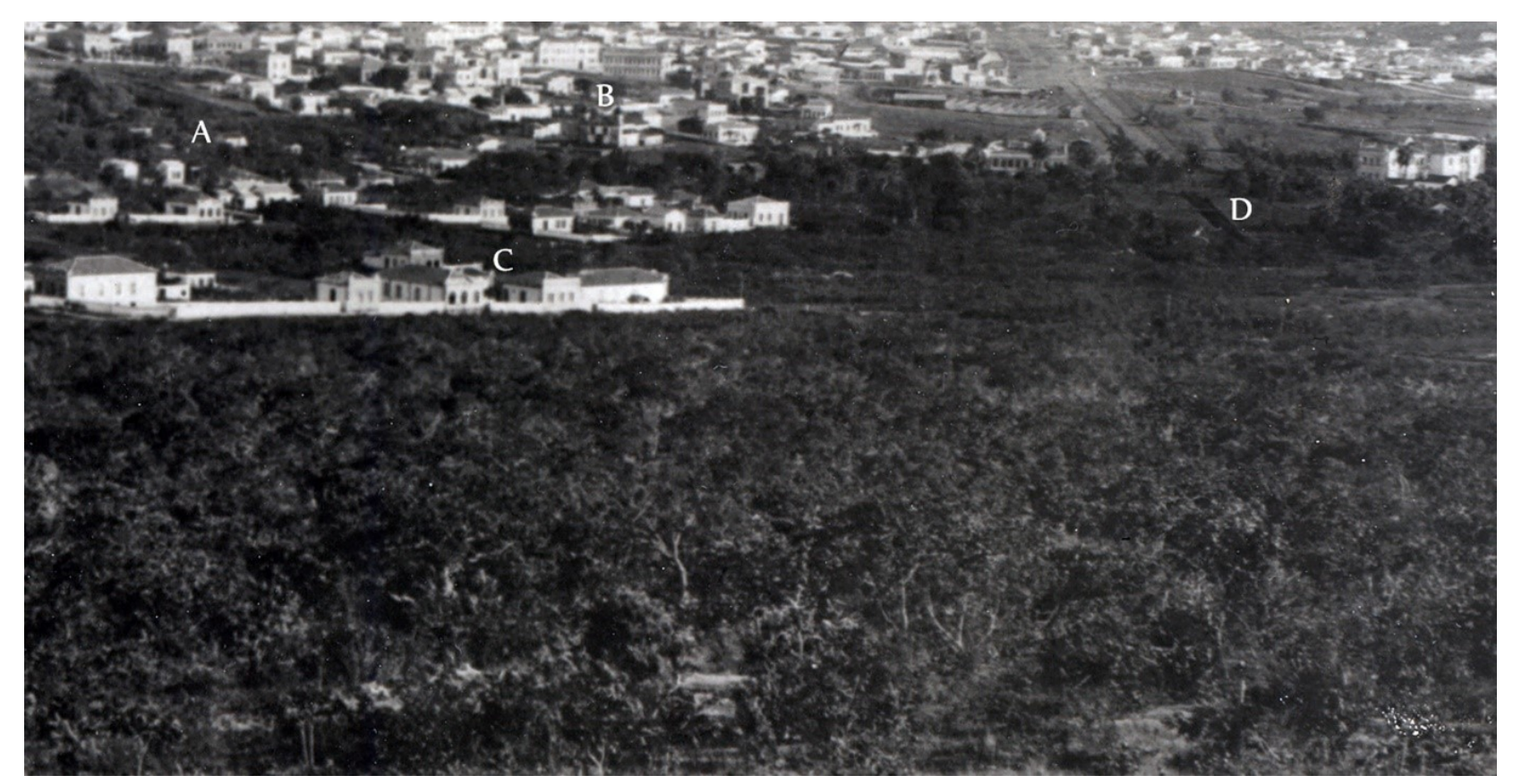

Figura 4 - Perspectiva N do vale do córrego do Acaba Mundo a partir da sua vertente leste, data atribuída: 1898/1900.

Detalhe para alguns elementos contidos na fotografia, como a Rua do Capão (A), a Matriz da Boa Viagem (B), algumas casas ainda existentes na Rua Paraibuna (Professor Morais) (C) e o canal parcialmente construído para as águas do Acaba Mundo (D) alinhado à Avenida Afonso Pena, cujas obras de abertura também se encontravam interrompidas. Em meio às casas a mata ciliar do córrego do Acaba Mundo, que ainda corria em seu leito natural.

Fonte: Museu Histórico Abílio Barreto.

\subsection{Acaba Mundo e a nova capital (1897/1920)}

Nas três primeiras décadas que se sucederam à inauguração da nova capital, o córrego do Acaba Mundo continuou a correr em seu leito natural, assim como os demais cursos d'água afluentes da margem sul do ribeirão Arrudas (BORSAGLI, 2016). A Prefeitura de Belo Horizonte não possuía recursos para promover a expansão urbana além dos limites estabelecidos pela CCNC para uma população de trinta mil habitantes (FJP, 1997). 
De acordo com as diretrizes estabelecidas pela CCNC no ano de 1897, a ocupação urbana na zona planejada se concentrou ao sul no bairro dos Funcionários (Avenida Cristovão Colombo), ao norte em parte dos bairros Floresta e Santa Efigênia (Avenidas Araguaia e Tocantins), à oeste limitada pelo ribeirão Arrudas, no trecho correspondente ao bairro comercial, entre o Parque Municipal e o Barro Preto, englobando as Avenidas do Comercio, Afonso Pena e na Rua da Bahia, onde se concentravam grande parte das casas comerciais e residências da população de maior poder aquisitivo, e à leste pela Avenida do Contorno.

No entanto, a evolução urbana extrapolou os limites estabelecidos, onde se destacam o adensamento no bairro de Santa Efigênia (microbacia do córrego da Serra) e na porção correspondente ao bairro operário do Barro Preto (microbacia do córrego do Barro Preto/Leitão). Apesar do crescimento urbano sobre as bacias hidrográficas da zona urbana planejada, nos primeiros anos da nova capital ocorreram apenas intervenções pontuais no ribeirão Arrudas, no trecho compreendido entre as ruas Espirito Santo e Tupinambás, construção de pontes sobre os cursos d'água sem alterar o leito original (BELO HORIZONTE, 1900) e de bueiros que possibilitassem a drenagem das águas pluviais, considerado no período um dos mais graves problemas decorrentes da abrupta extinção da Comissão Construtora.

A retificação e a canalização dos cursos d'água da zona urbana planejada, em particular o Acaba Mundo, também eram motivos de preocupação por parte da prefeitura, pois as obras possibilitariam a urbanização e a venda de lotes do bairro dos Funcionários ainda em conclusão, visto que o curso d'água, que continuava em leito natural impossibilitava a ocupação plena de diversos lotes planejados sobre o seu curso:

Resta por concluir-se o canal destinado à mudança do leito do Acaba Mundo, que parte da Rua Grão Mogol suburbana e vai ao Parque. Essa obra, aliás necessária, foi iniciada pela antiga Comissão Construtora e está parada desde 1897, e dela não poderá cogitar tão cedo (BELO HORIZONTE, 1900, p.31).

Nesse período, a bacia do córrego do Acaba Mundo apresentava duas ocupações distintas dentro do perímetro da nova capital: a porção que se encontrava à montante da Avenida do Contorno foi transformada em uma das cinco colônias agrícolas criadas pelo Estado nos anos de 1898 e 1899. A Colônia Adalberto Ferraz existiu por cerca de quinze anos, sendo anexada à zona suburbana de Belo Horizonte, sendo que o seu traçado apresentava características de ordem morfológica que se assemelhava ao plano elaborado pela CCNC para a zona suburbana (AGUIAR, 2006). Já a porção a jusante da Avenida do Contorno corresponde ao bairro Funcionários, que no período se encontrava parcialmente urbanizado, uma vez que o curso d'água em leito natural impossibilitava a regularizada das vias e dos quarteirões planejados.

Para possibilitar a continuidade da expansão urbana do bairro Funcionários no vale do Acaba Mundo, nos primeiros anos do século XX foram construídas diversas pontes de alvenaria de pedra 
com arco de alvenaria de tijolo requeimado, ao mesmo tempo em que se realizou a construção de uma galeria coberta sobre o córrego do Acaba Mundo entre as ruas Paraíba e Pernambuco para a continuidade da expansão urbana em um importante local, além da canalização de cerca de cinquenta metros do córrego entre a Avenida do Contorno e Rua Antônio de Albuquerque (BORSAGLI, 2016).

Essas foram as principais intervenções realizadas no Acaba Mundo no referido período, ainda que o tecido urbano de Belo Horizonte tenha se expandido de maneira contínua sobre a porção urbana da bacia, destacando-se ainda algumas observações realizadas por Penna (1997) a respeito do Acaba Mundo, onde se pode concluir ao relacionar os relatórios das administrações municipais, as imagens produzidas no período 1898/1928 e as informações abaixo que o curso d'água não se encontrava completamente canalizado no ano de 1897 como afirmou Botelho Almeida (2019), ao se referir às intervenções iniciadas (e interrompidas) no Acaba Mundo pela CCNC dentro da zona urbana planejada ${ }^{1}$ :

- 21 de março de 1902: "A colocação dos trilhos para as linhas de bondes prossegue com intensidade. Os serviços são iniciados na Avenida Afonso Pena. Foram concluídos os pregões da ponte sobre o Acaba Mundo (Figura 5), em frente à Distribuidora” (PENNA, 1997, p.75).

- 30 de outubro de 1911: “O presidente do Estado visita a pequena usina hidrelétrica instalada pela Prefeitura, no Parque, para a própria iluminação desse logradouro, utilizando as águas do Acaba-Mundo" (PENNA, 1997, p.125).

- 27 de abril de 1912: “A Prefeitura noticia, para breve, a conclusão de várias obras de saneamento: o escoamento das águas e aterro de uma área alagadiça junto à estação; galerias coletoras de águas pluviais da rua dos Caetés para o Arrudas e das ruas Piauí e Pernambuco para o Acaba-Mundo; canalização desse curso sob a Avenida Paraúna com a ponte da rua Cláudio Manoel” (PENNA, 1997, p.129).

- 8 de junho de 1913: "O primeiro desastre de automóvel em que falece um passageiro ocorre em Belo Horizonte. O automóvel $n^{0}$ 70, vindo da Pedreira do Acaba-Mundo, no cruzamento das ruas Paraíba com Bernardo Guimarães, junto à ponte ali existente, projetou-se ao leito do córrego. Com o acidente, faleceu logo o passageiro F. de Amorim Caridade e gravemente feridos ficaram os demais passageiros" (PENNA, 1997, p.140-141).

\footnotetext{
${ }^{1}$ Revista do Arquivo Público da Cidade de Belo Horizonte (2019, p.56).
} 


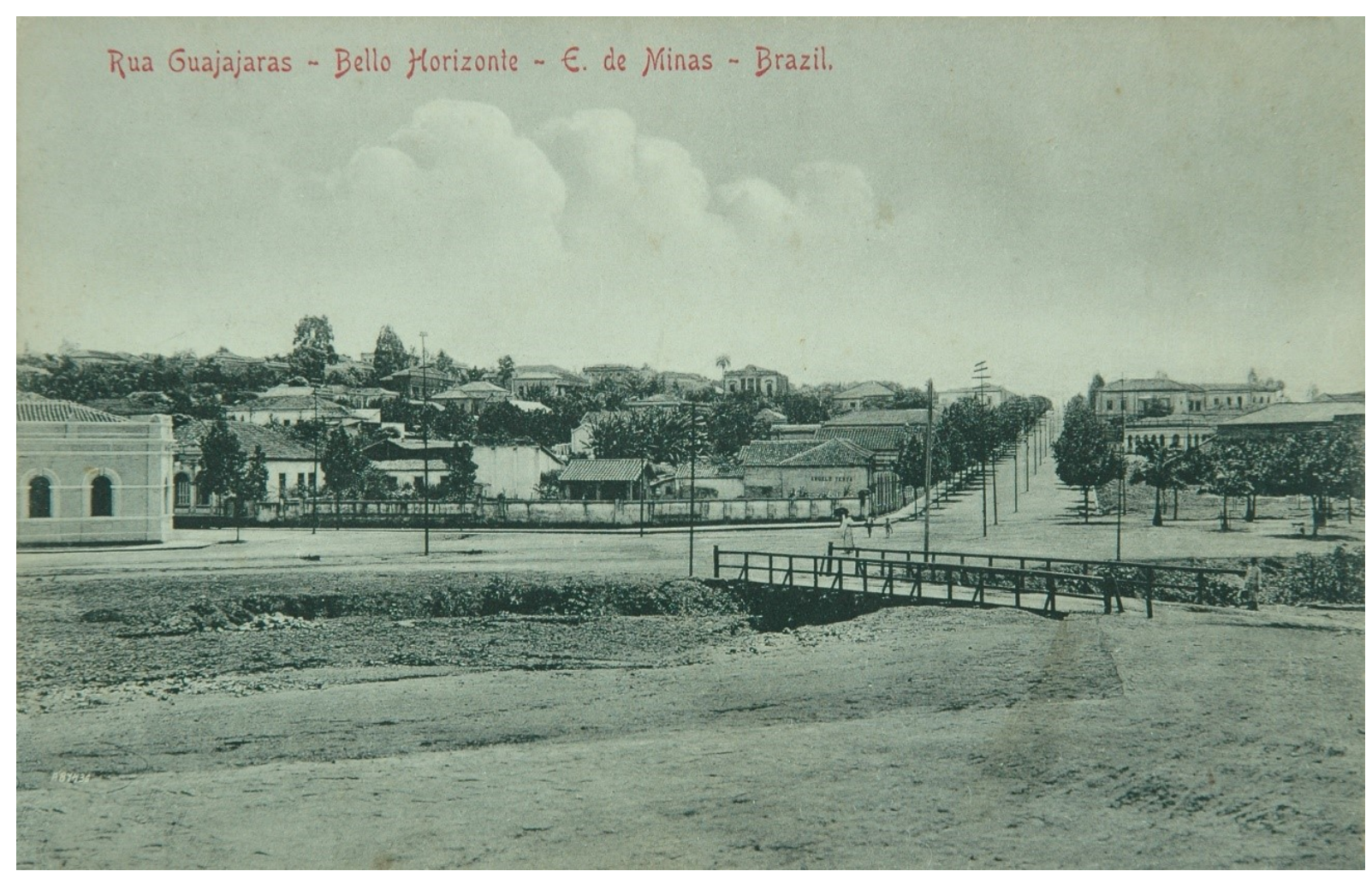

Figura 5 - Ponte sobre o córrego do Acaba Mundo, no cruzamento da Avenida Afonso Pena e Rua Guajajaras. Fonte: Museu Histórico Abílio Barreto.

\subsection{Acaba Mundo: primeiras intervenções (1920/1930)}

A primeira metade da década de 1920 caracterizou-se pela rápida expansão urbana de Belo Horizonte, que obrigou o poder público a retomar as obras de urbanização e infraestrutura urbana nos vales dos córregos do Leitão e do Acaba Mundo (BORSAGLI, 2016), visto que a incompatibilidade entre a rede hidrográfica e o traçado geométrico, a partir desta década se mostrou de maneira mais ampla no sítio, onde inúmeras vias planejadas se encontravam interrompidas ou atravessadas pelos fundos de vale dos cursos d'água (Figura 6), fatores que não permitiam a urbanização e venda de lotes em inúmeros pontos da zona urbana planejada.

Nesse sentido, no ano de 1920 foram iniciadas as obras de cobertura do córrego do Acaba Mundo na Rua Alagoas (PENNA, 1997), e no ano de 1923 foram cobertos cerca de vinte e oito metros do leito natural do curso d'água entre a ponte da Rua Pernambuco e a Rua Bernardo Guimarães, permitindo o prolongamento da Avenida Brasil e a urbanização do local (BORSAGLI, 2016). As intervenções, ainda que realizadas de maneira pontual, era o exemplo do modelo que seria adotado pelo poder público para a rede hidrográfica do município, onde grande parte do leito natural dos cursos d'água seriam convertidos em galerias pluviais, ou aquedutos (BELO HORIZONTE, 1928) em abóbada de alvenaria e as águas desviadas para canais artificiais construídos de acordo com a geometria da cidade planejada, sendo o Acaba Mundo o protagonista das intervenções que seriam realizadas nos afluentes do ribeirão Arrudas. 


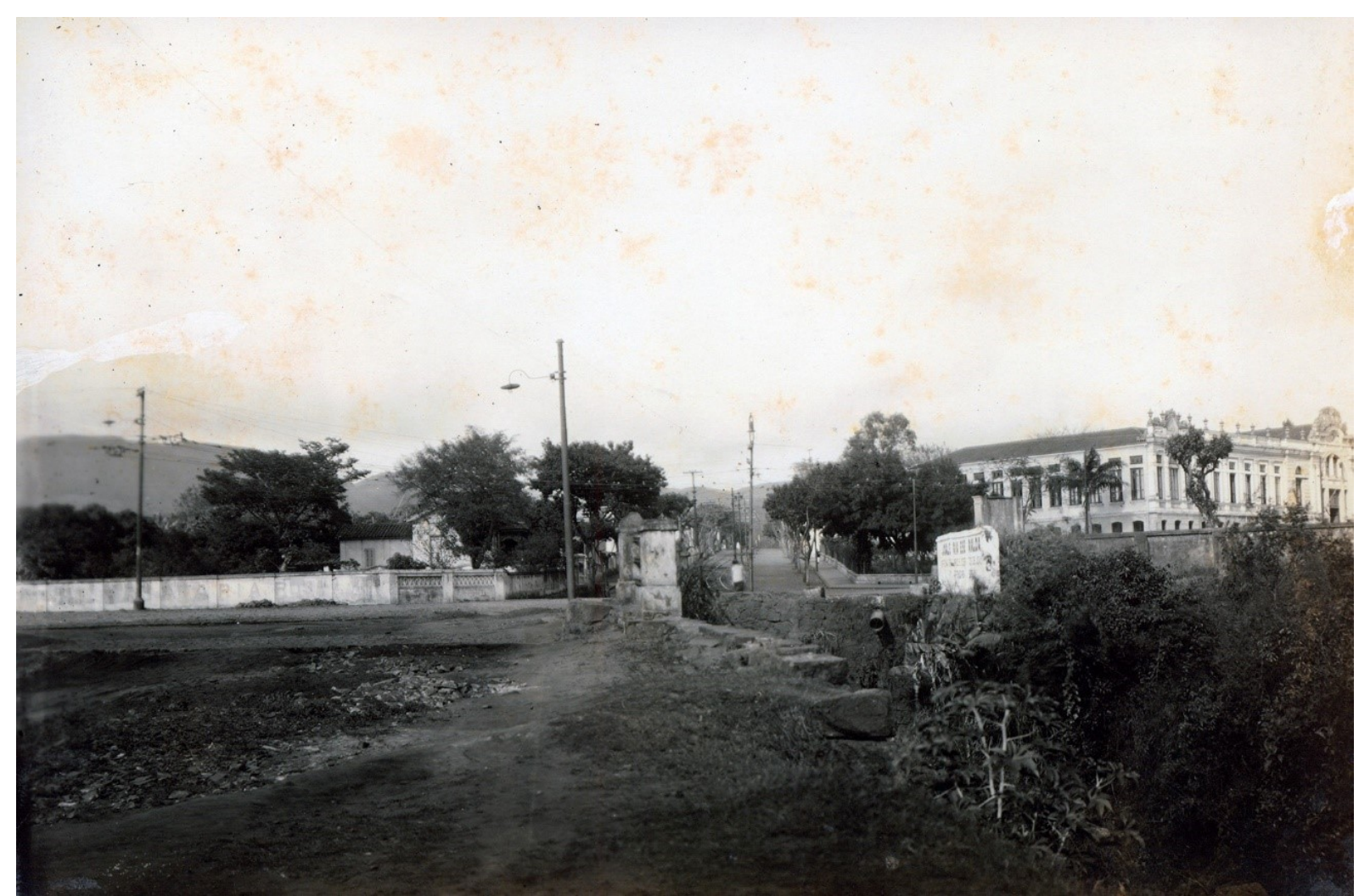

Figura 6 - ponte da Avenida Paraúna sobre o córrego do Acaba Mundo em 1920, no cruzamento da Rua Rio Grande do Norte. Nesse trecho as duas vias se encontravam interrompidas pelo curso d'água em leito natural, tornando-se explicita a incompatibilidade entre o leito do curso d'água e o traçado geométrico.

Fonte: Museu Histórico Abílio Barreto.

As canalizações buscaram resolver ainda o problema da poluição hídrica, visto que os esgotos eram despejados in natura nos cursos d'água desde a inauguração da capital (BORSAGLI, 2016). Ou seja, o condicionamento da rede hidrográfica ao traçado de Belo Horizonte possibilitou a construção de interceptores ao logo dos canais construídos, evitando assim o despejo nos cursos d'água.

Nesse contexto, as obras de construção do canal na Rua Professor Morais e Avenida Afonso Pena foram retomadas no final de 1926, após o abatimento da abóbada de alvenaria em alguns trechos do canal (Figuras 7 e 8), ocasionados por defeitos de construção e insuficiência de fundações (BELO HORIZONTE, 1926). Nesse contexto, é importante observar que as obras de retificação e canalização do córrego do Leitão haviam sido iniciadas no ano de 1924, após a retomada das obras no leito natural do Acaba Mundo.

O vale do córrego do Leitão, diferentemente do Acaba Mundo, apresentava uma paisagem tipicamente rural, com poucas intervenções de ordem urbana e estrutural. Possivelmente, a administração municipal julgou necessária a intervenção em uma área desprovida de infraestrutura e altamente valorizada, deixando a construção e a conclusão das obras no Acaba Mundo para serem retomadas após o término das obras no Leitão, sendo que a primeira parte das intervenções findaram no ano de 1926 (BORSAGLI, 2016). 

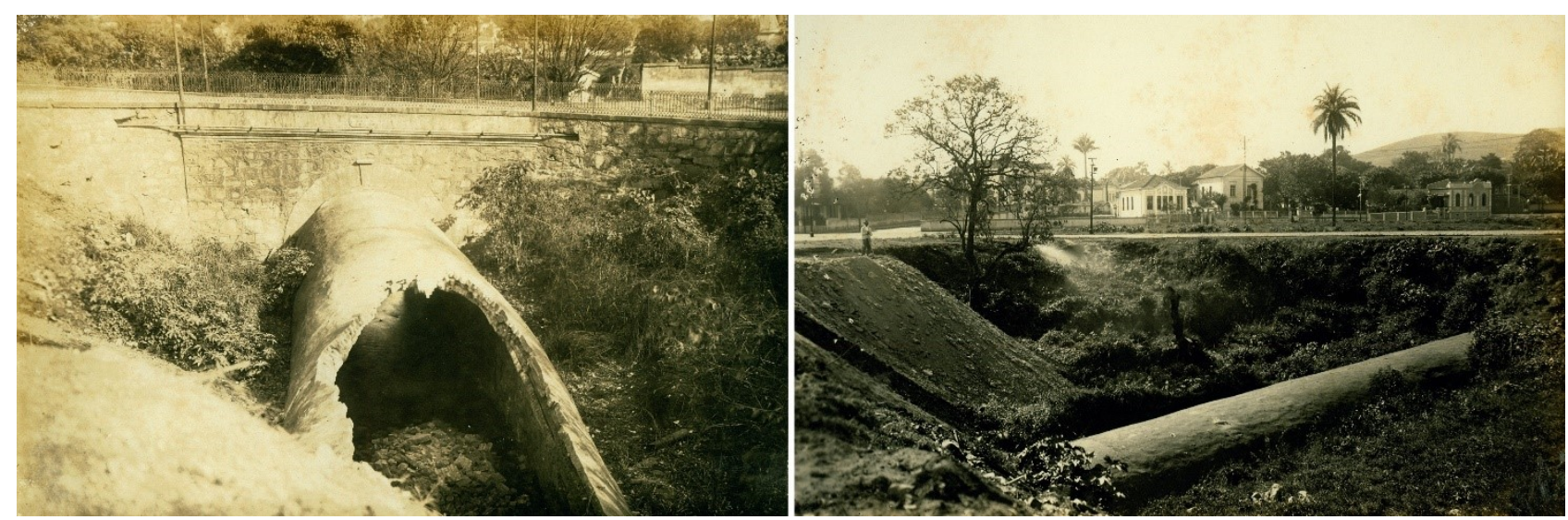

Figuras 7 e 8: Galeria de abóbada de alvenaria construída no leito natural do córrego do Acaba Mundo no ano de 1926. Detalhe para a galeria abatida na ponte da Rua Pernambuco e o aqueduto construído no leito natural, no cruzamento da Avenida Brasil e Rua Bernardo Guimarães.

Fonte: Museu Histórico Abílio Barreto.

Entre os anos de 1927 e 1929 o Acaba Mundo foi desviado para um canal de cerca de 1.550 metros de extensão, passando a correr pelas Rua Professor Morais e Avenida Afonso Pena. Para a conclusão da obra foram construídas onze pontes para transpor o canal, todas em concreto armado, no mesmo instante em que as demais pontes sobre o antigo leito desapareceram com a canalização e o aterramento deste, com material proveniente da terraplanagem da Praça do Cruzeiro ${ }^{2}$, realizado no mesmo período da canalização, proporcionando ao município a venda e a urbanização dos quarteirões surgidos após o aterramento. No antigo canal do Acaba Mundo foi construído um dreno com o intuito de receber todo o escoamento das águas pluviais e das bocas de lobo da região, onde as galerias construídas nas duas primeiras décadas da capital seriam transformadas em câmaras de visita, com o acesso passando a ser feito pelos poços de visita construídos para tal finalidade (Figuras 9 e 10).

A canalização permitiu a conclusão das vias do bairro Funcionários e a comercialização dos lotes de treze quarteirões, urbanizados a partir do soterramento do antigo leito do curso d'água e do córrego do Mendonça, afluente da margem oeste que atravessa parte do bairro (BORSAGLI, 2016), também canalizado em seção fechada. O córrego do Gentio, principal afluente do Acaba Mundo, foi canalizado apenas nos seus metros finais, permanecendo o restante em leito natural, no trecho correspondente ao bairro Anchieta.

As intervenções na rede hidrográfica realizadas entre os anos de 1923 e 1930 acabaram por inserir os córregos do Acaba Mundo, Leitão e o ribeirão Arrudas na paisagem da zona urbana planejada, vistos como um elemento que integrava o ambiente construído e o meio, ambos controlados pelo racionalismo geométrico da cidade planejada (Figura 11). O córrego da Serra, canalizado no mesmo período dentro da zona urbana planejada desapareceu da paisagem urbana, tornando-se o primeiro curso d'água a ser canalizado em seção fechada por questões econômicas.

\footnotetext{
2 Praça Milton Campos. 

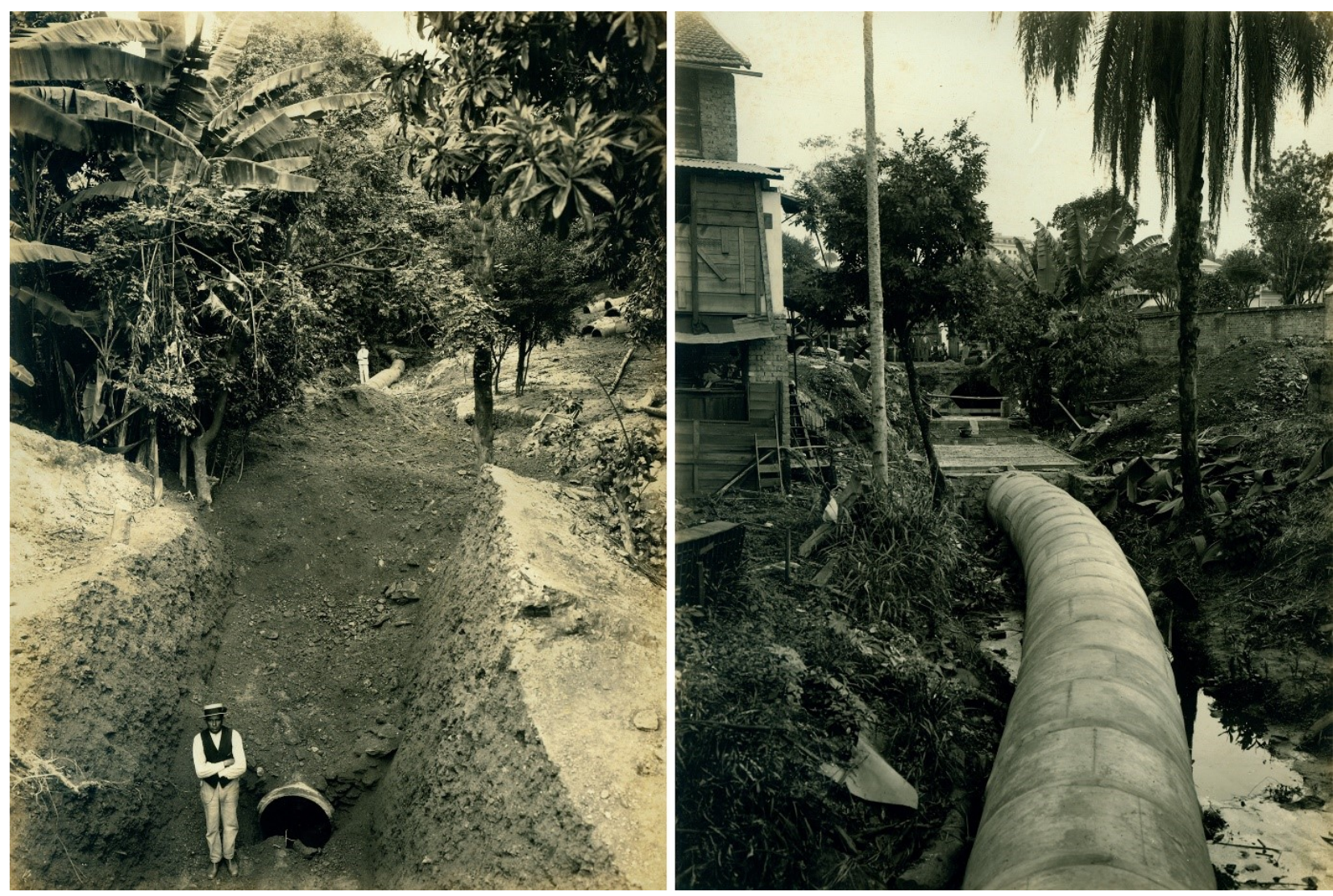

Figuras 9 e 10 - Construção do dreno e aterramento do antigo leito do Acaba Mundo no bairro Funcionários, 1928. Fonte: Museu Histórico Abílio Barreto.

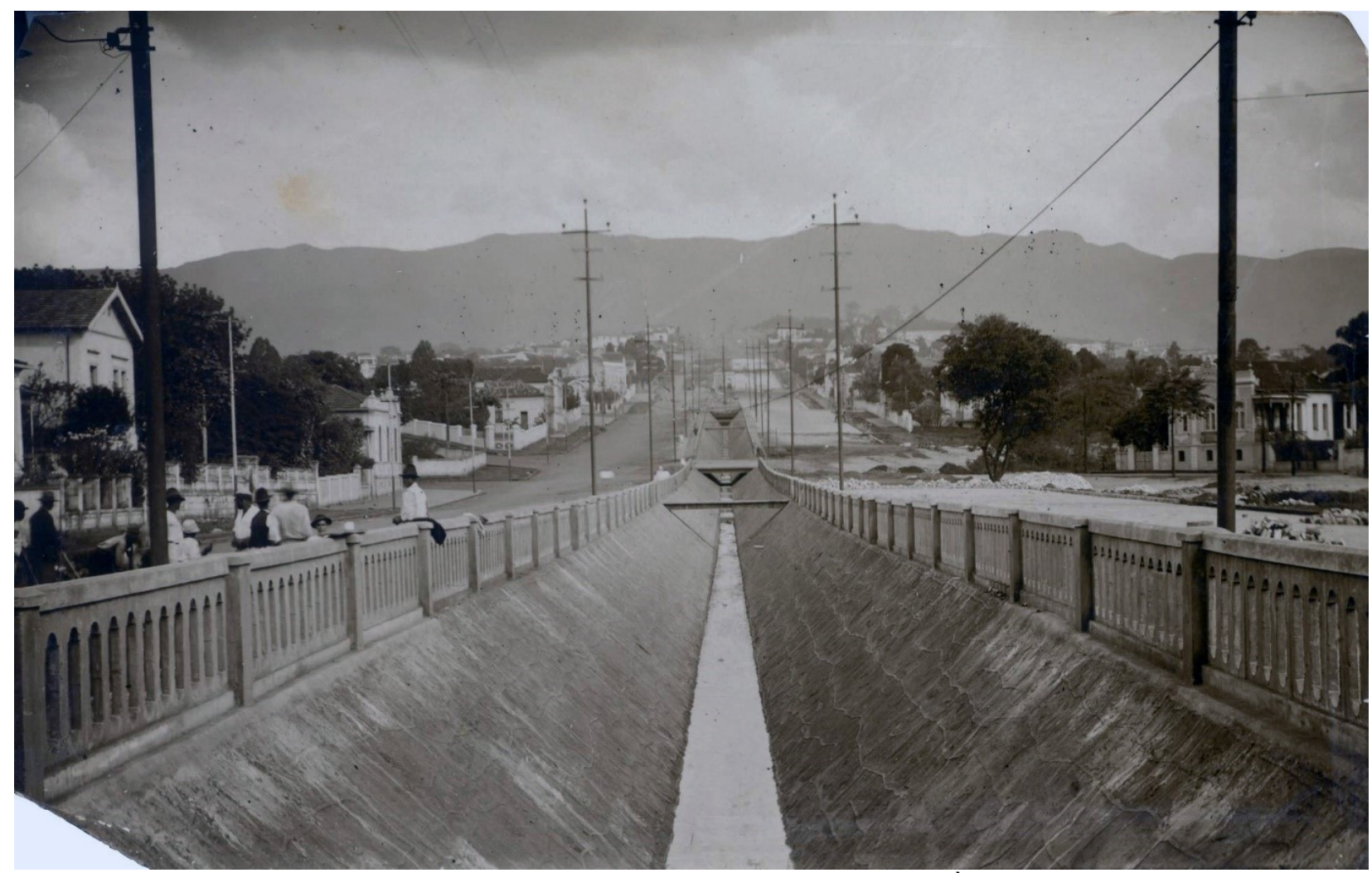

Figura 11 - Canal do córrego do Acaba Mundo na Avenida Afonso Pena, 1928. À direita o local por onde passava o antigo leito do curso d'água, em fase final de aterramento (Rua Bernardo Guimarães).

Fonte: Arquivo Público Mineiro. 


\subsection{Acaba Mundo: da intervenção à invisibilidade (1930/1973)}

A conclusão da canalização do Acaba Mundo na zona urbana planejada pode ser considerada parte da materialização na paisagem urbana dos planos da CCNC para a nova capital, onde o líquido elemento e o elemento vergel deveriam ser controlados pela racionalidade técnica imposta pelo traçado geométrico. A retirada do curso d'água do seu leito natural e o aterramento da calha e a urbanização do leito maior possibilitaram um retorno considerável para o erário municipal, a partir da comercialização dos lotes projetados nas terras em que eram atravessadas pelo curso d'água. No entanto as intervenções realizadas, entre outros fatores de ordem urbana, proporcionaram o surgimento dos transbordamentos em locais que até então não apresentavam tal fenômeno, uma vez que as planícies de inundação não existiam mais, desaparecidas sob uma cidade que impermeabilizava cada vez mais suas microbacias hidrográficas (BORSAGLI, 2019).

Ao mesmo tempo em que o Acaba Mundo transbordava no bairro Funcionários, a queda da República Oligárquica no final de 1930 e a ascensão de Getúlio Vargas ao poder trouxeram profundas mudanças políticas, econômicas, sociais e urbanas no Brasil. O contexto político do período proporcionou a mudança na relação entre o governo e a classe operária, acelerando ainda o crescimento e o desenvolvimento dos centros urbanos brasileiros a partir da industrialização das grandes cidades nos anos seguintes à revolução. Nesse contexto, a nova ordem política não interrompeu o crescimento urbano e econômico de Belo Horizonte, ao mesmo tempo em que proporcionou a consolidação de um modelo urbano que nas três décadas seguintes alterou profundamente a relação entre a cidade e os elementos naturais (BORSAGLI, 2016).

Entre as décadas de 1940 e 1960 o acentuado crescimento populacional e urbano da capital mineira, a alta impermeabilização e as alterações ocorridas no regime hídrico da porção correspondente ao médio e baixo Arrudas tornaram os transbordamentos de fundo de vale mais frequentes, ao mesmo tempo em que a poluição hídrica aumentava devido à falta de interceptores de esgotos nas bacias. O Acaba Mundo, até meados da década de 1940, se encontrava livre do despejo direto de esgotos (FONSECA, 1951), visto que o emissário construído ao longo do canal comportava a quantidade de esgotos gerados nos bairros assentados em sua microbacia. No entanto, a partir da expansão urbana para as suas cabeceiras e dos seus afluentes, o curso d'água passou a receber novamente o despejo in natura dos efluentes domésticos e dos detritos provenientes das movimentações de terra dos novos bairros (BORSAGLI, 2016).

Tais fatores não se restringiam ao Acaba Mundo, uma vez que a capital passou a crescer para todas as direções a partir da primeira metade da década de 1950, quando se inicia o processo de metropolização de Belo Horizonte, processo que contribuiu de maneira decisiva para a mudança da relação entre a cidade e os elementos naturais presentes na paisagem urbana. Em meio ao processo 
de metropolização o asfalto, presente nas políticas municipais desde a década de 1920, foi transformado na gestão municipal de Juscelino Kubitscheck como um dos elementos que representavam a modernidade, passando a ser empregado em larga escala a partir de então. Nas gestões seguintes ele passou a ser vendido não somente como símbolo da modernidade, mas também como um elemento embelezador da paisagem urbana encontrando no automóvel, tido a partir da década de 1950 como o símbolo do progresso, de status e de distinção social o seu par, fatores bem assimilados pelas sociedades urbanas brasileiras no decorrer do século XX (LUCHEZI, 2010).

A rede hidrográfica da zona urbana planejada de Belo Horizonte, tida até então como um elemento de referência na paisagem urbana e de cunho embelezador, passaram a ser vistos como um obstáculo para a evolução urbana, ao mesmo tempo que os cursos d'água em meio urbano eram tidos como condutores de doenças ligadas ao consumo e contato com a água a partir dos transbordamentos ou da falta dela, uma vez que Belo Horizonte se encontrava desde a década de 1930 no limiar do desabastecimento, que seria resolvido apenas no ano de 1973 (MESQUITA, 2013).

Nesse contexto, o trecho canalizado do córrego do Acaba Mundo, entre os anos de 1948 e 1962 passou por inúmeros transbordamentos que acarretaram em perdas materiais e transtornos que não ocorriam de maneira frequente no tempo em que o curso d'água se encontrava em leito natural. A enchente ocorrida em fevereiro de 1948 foi considerada a mais grave ocorrida até então em Belo Horizonte. O transbordamento atingiu com maior magnitude a zona urbana planejada, correspondente aos vales do ribeirão Arrudas e os córregos do Leitão, Serra e parte do canal do córrego do Acaba Mundo e do seu antigo leito natural que se encontrava aterrado e urbanizado, além de parte da zona suburbana:

Os bairros do Carmo e Santa Efigênia foram duramente atingidos. A Rua Grão Mogol estava entulhada de tijolos de muros que havia desabado. Abriram-se buracos nas outras vias. Viamse ainda arvores arrancadas pelas enxurradas. O mesmo se pôde observar na Rua Professor Morais e rua rio Grande do Norte, (...) (Estado de Minas, 29 de fevereiro de 1948, p.4).

É importante observar que após o transbordamento de 1948 o curso d'água teve suas laterais de alvenaria de pedra argamassada removidas, com a finalidade de aumentar a vazão na Rua Professor Morais, ao mesmo tempo em que foi construído um canal em seção fechada que transportava parte das águas coletadas pelo canal principal pelas ruas Tomé de Souza e Rio Grande do Norte, ressaltando que uma parte da alvenaria continuou a existir na Avenida Afonso Pena, ou seja, toda a água excedente transportada pelo canal da Rua Professor Morais nos períodos chuvosos era retida na Avenida Afonso Pena, fato que tornou os transbordamentos regulares até o ano de 1962 (Figura 12). 


\section{ESTADO DE MINAS - -}

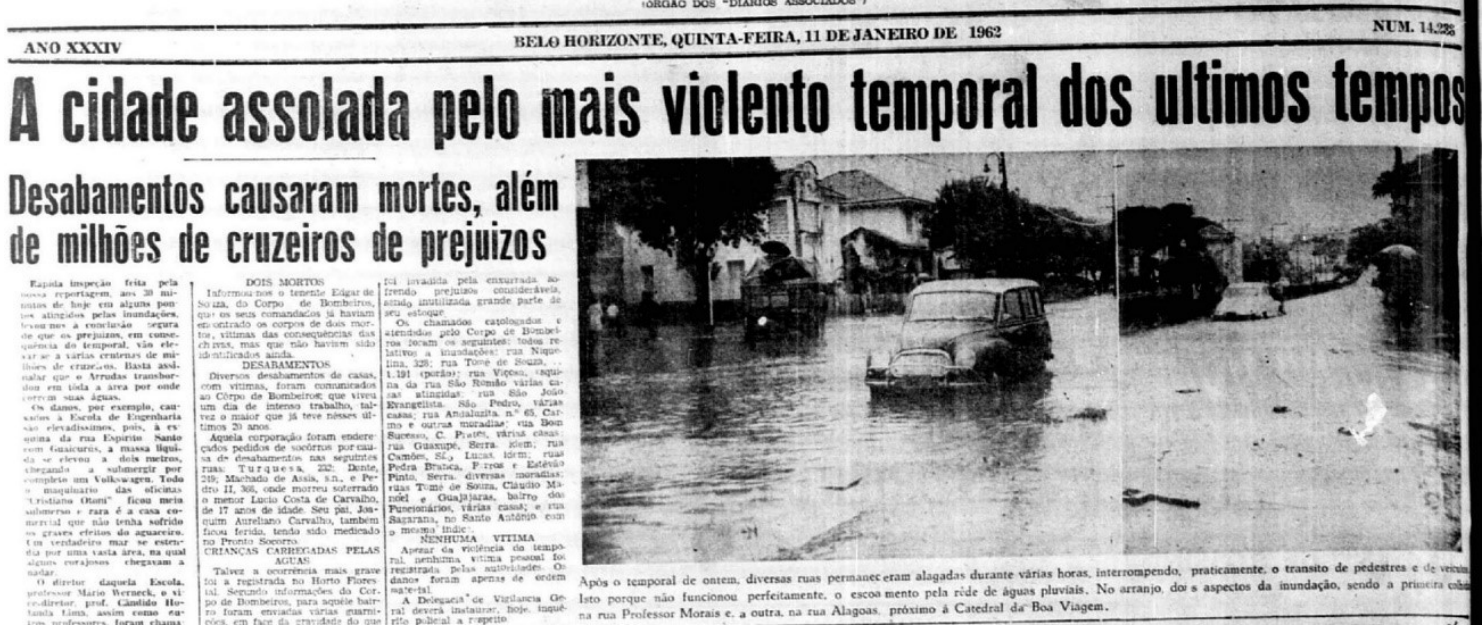

Figura 12 - Notícias e imagens do transbordamento do córrego do Acaba Mundo, janeiro de 1962. Fonte: Hemeroteca Histórica de Minas Gerais.

Desde a segunda metade da década de 1950 as políticas públicas de Belo Horizonte tinham o asfalto e o automóvel como protagonistas, ao mesmo tempo em que a presença dos cursos d'água em leito aberto era cada vez mais rechaçada pela população (BORSAGLI, 2016), que sofria com os efeitos decorrentes da poluição hídrica e com as consequências dos transbordamentos de fundos de vale, cada vez mais frequentes. Nesse sentido, os planos apresentados pelas gestões de Jorge Carone (1963/1965) e Oswaldo Pieruccetti (1965/1967) para resolver os problemas de ordem viária, fluvial e sanitária seguiam duas premissas básicas: a canalização, cobertura e alargamento dos canais de diversos cursos d'água urbanos e o asfaltamento dos logradouros, diminuição das calçadas e a abertura de novas vias.

Dentro dos planos de estabelecidos pelo poder público para a capital mineira, o córrego do Acaba Mundo seria mais uma vez o protagonista da profunda reforma urbana que alterou a partir da segunda metade da década de 1960 a paisagem urbana de Belo Horizonte. Entre os anos de 1963 e 1965 o canal do curso d'água foi alargado, aprofundado e coberto na Rua Professor Morais (Figura 13), a partir da justificativa de controle dos transbordamentos, melhoria sanitária e viária (BORSAGLI, 2016).

A partir dessa nova estética e um dos protagonistas das primeiras intervenções na rede hidrográfica de Belo Horizonte, o córrego e suas balaustradas, local de materialização da natureza controlada pela cidade, passou de um símbolo de beleza e afirmação do lugar para um símbolo de degradação e negação dos elementos naturais em meio urbano, onde a cobertura do Acaba Mundo inaugurou uma nova estética urbana com o desaparecimento da rede hidrográfica da paisagem urbana, consolidada em âmbito municipal pelas gestões de Oswaldo Pieruccetti (1965/1966 e 1971/1975) e Luís Gonzaga de Sousa Lima (1967/1971). 

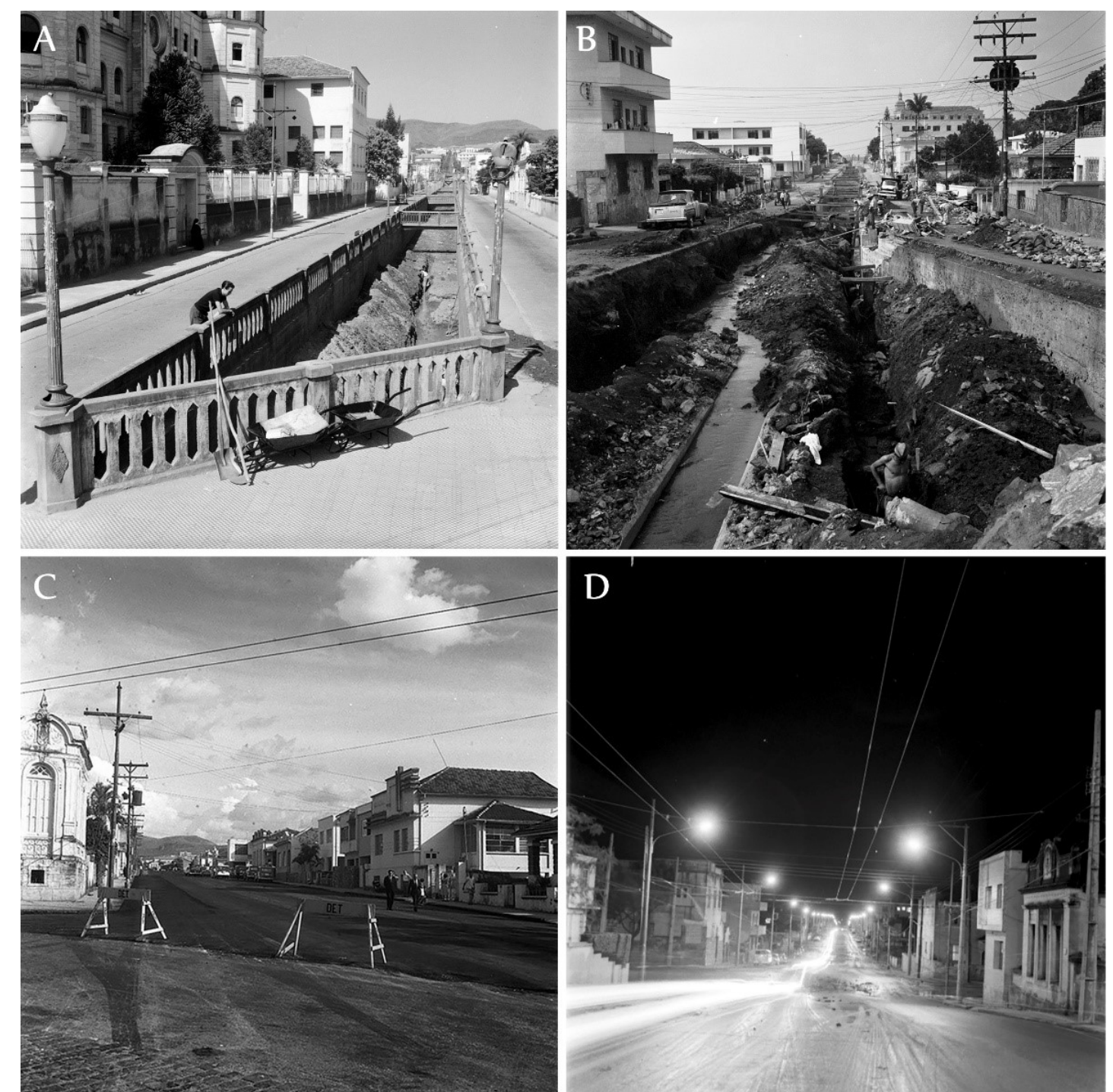

Figura 13 - Perspectivas do canal do córrego do Acaba Mundo na década de 1960: vista do canal à montante na Rua Professor Morais, 1963 (A), obras de alargamento e aprofundamento, outubro de 1963 (B), o canal coberto no cruzamento com Avenida Afonso Pena, 1965 (C) e vista noturna da Rua Professor Morais após o término das obras, 1965 (D).

Fonte: Arquivo Público da Cidade de Belo Horizonte.

Nos anos que se sucederam, o curso d'água, que se encontrava coberto desde a BR-3 até a Avenida Afonso Pena, passou por mais uma intervenção, uma vez que o pequeno canal da Rua Outono se encontrava sobrecarregado. A antiga canalização foi substituída por uma galeria de concreto de 2,80 metros de largura por 2,80 metros de altura com a finalidade de receber toda a água das vertentes impermeabilizadas dos bairros Sion e São Pedro para se evitar as inundações naquela região (BELO HORIZONTE, 1966), ao mesmo tempo em que o canal foi alargado e aprofundado na Avenida Afonso Pena.

As obras executadas integravam o programa de reforma urbana intitulado Nova BH-66, surgido a partir de uma parceria estabelecida entre a Prefeitura e a Escola de Arquitetura da Universidade Federal de Minas Gerais e criado com o objetivo de realizar a melhoria na infraestrutura urbana de Belo Horizonte, que apresentava sinais de colapso desde a década de 1950. Em sete anos, 
quase todos os cursos d'água localizados na região centro-sul foram cobertos, com o intuito de promover a urbanização e comercialização dos lotes localizados nos bairros construídos pela Companhia Urbanizadora da Serra do Curral (CIURBE), criada a partir da parceria firmada entre as administrações municipal e estadual para a comercialização de terrenos destinados à parcela da sociedade de maior poder aquisitivo, que buscava alternativas de moradia em meio a congestão urbana da região central que atingiu o seu ápice no período (BORSAGLI, 2019).

Nesse contexto, o córrego do Acaba Mundo praticamente desapareceu da paisagem urbana, tornando-se visível apenas na Avenida Afonso Pena até o ano de 1980, e no trecho correspondente à Vila Acaba Mundo e adjacências. Com a consolidação do bairro Sion o curso d'água passou a receber uma grande contribuição de esgotos domésticos e detritos oriundos da intensa movimentação de terra e da precária coleta de lixo descartados ao longo do seu leito natural, além do surgimento de uma pequena favela erradicada com a abertura da Avenida Uruguai (BORSAGLI, 2016). Nesse treco, o Acaba Mundo foi canalizado e coberto entre os anos de 1972 e 1973 e a cidade "ficou mais bonita no domingo com a nova avenida no bairro Sion" (Diário de Minas, 1 de julho de 1973, p.5) aberta com o objetivo de atender à crescente demanda viária de uma região em acentuada expansão e de grande importância para o erário municipal.

$\mathrm{Na}$ inauguração da avenida foi grande o número de moradores que compareceram ao evento, capitaneado pelo prefeito, que sob faixas com os dizeres $O$ Acaba Mundojá era, realizou a caminhada sobre o curso d'água canalizado sob justificativas estéticas, hidráulicas e sanitárias que em parte nortearam a criação de Belo Horizonte (BORSAGLI, 2016).

As propagandas e matérias pagas pela prefeitura no período procuravam resgatar os ideais modernistas e progressistas que nortearam o projeto e a construção da capital, perpetuados e adaptados por quase todas as administrações municipais desde 1898, para justificar as obras empregadas e projetadas para a cidade. Contudo, no caso do Acaba Mundo, a "hidrofobia" do poder público chegou ao seu ápice, com a veiculação de propagandas com a frase O Acaba Mundo já era. Ele virou Avenida Uruguai, afirmando que a região não poderia continuar com aquele córrego malcheiroso interrompendo a avenida e deveria ser erradicado em nome do progresso, exaltando a participação da população na execução das obras.

Nesse sentido, o curso d'água se tornou o protagonista da invisibilidade, a partir das campanhas realizadas pela prefeitura de Belo Horizonte no período 1963-1975, ficando evidente qual eram os valores atribuídos pelo poder público à rede hidrográfica da capital (Figura 14), vista como entrave ao regular desenvolvimento urbano e desprovida de memória, ao mesmo tempo em que se atribuía ao elemento vergel um valor patrimônio coletivo e de memória afetiva e urbana. 

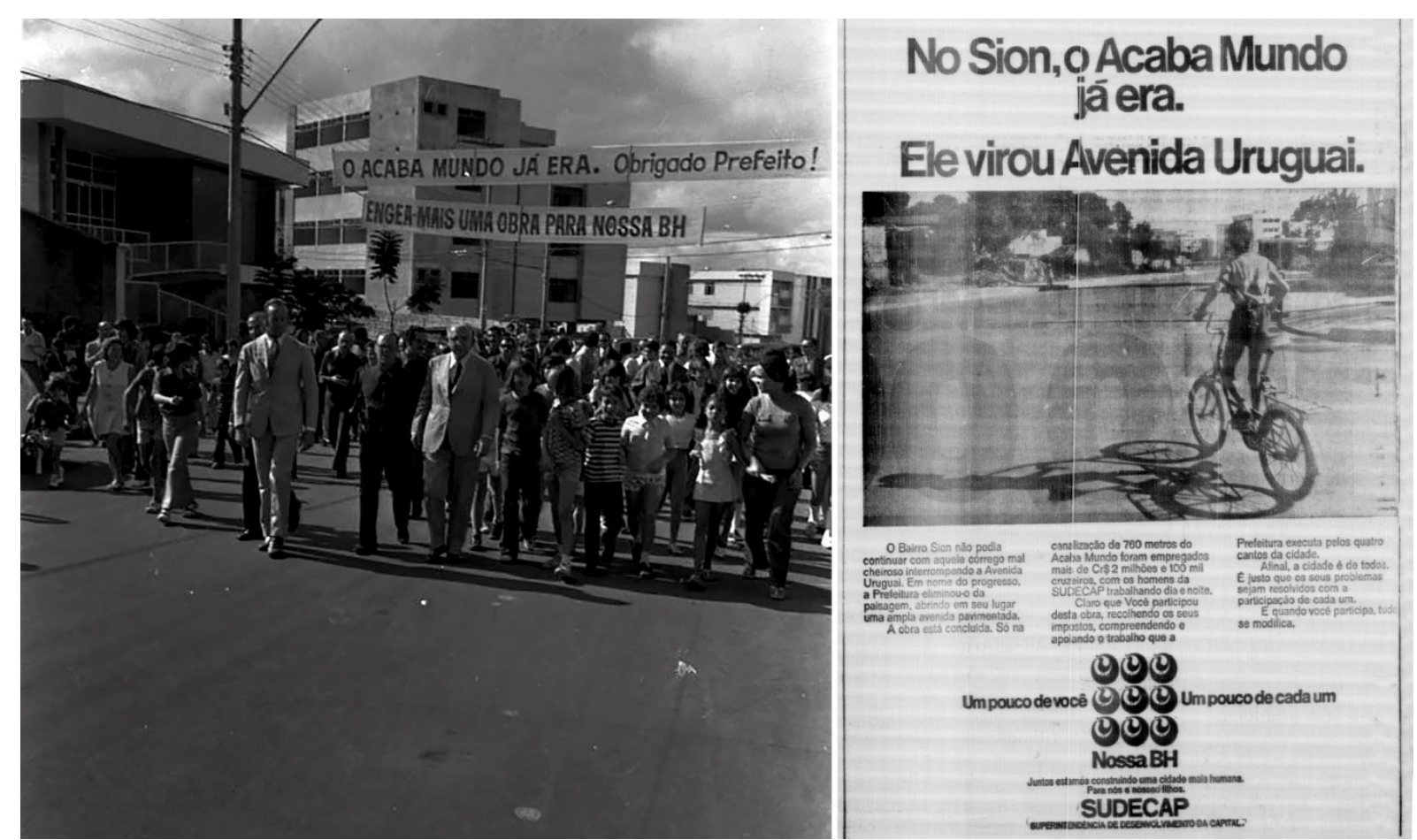

Figura 14 - Caminhada de inauguração da Avenida Uruguai e propaganda veiculada pela PBH, julho de 1973. Fontes: Arquivo Público da Cidade de Belo Horizonte e Diário de Minas.

\section{CONSIDERAÇÕES FINAIS}

O artigo buscou analisar, a partir da contextualização geográfica-histórica, a relação entre o sítio que abrigou o arraial de Belo Horizonte e posteriormente a nova capital de Minas Gerais e o córrego do Acaba Mundo, principal curso d'água do povoado e coberto ao longo do processo de evolução urbana de Belo Horizonte. A cobertura do córrego do Acaba Mundo e o seu desaparecimento da paisagem urbana podem ser consideradas emblemáticas para os estudos das intervenções fluviais no município de Belo Horizonte, uma vez que da sua bacia irradiaram-se para os demais afluentes do ribeirão Arrudas as técnicas e infraestruturas planejadas e empregadas nas diversas intervenções ocorridas a partir do ano de 1897.

O curso d'água e os processos que culminaram em sua cobertura podem ser considerados importantes exemplos das relações estabelecidas pelas sociedades urbanas do ocidente com os elementos naturais, que promoveram profundas reorganizações no espaço urbano em diversas cidades europeias (CASTONGUAY e EVENDEN, 2010), em geral de ordem estética, higiênica e ambiental, ainda que Botelho (2011, p.74), observa que desde a antiguidade os cursos d'água sofrem intervenções antrópicas, não apenas para o aumento do território a ser ocupado, mas também para a manutenção da vida (agricultura, criações, navegação etc.).

Nesse contexto, onde as políticas de cunho rodoviarista e sanitária embasam por cerca de um século as intervenções fluviais em meio urbano, a cobertura do Acaba Mundo iniciou-se no mesmo ano em que foram iniciadas a supressão das árvores das vias inseridas dentro da Avenida do 
Contorno consideradas um patrimônio ambiental urbano, ressaltando que a mesma parcela da sociedade que protestou contra o corte das árvores aplaudiu a cobertura do córrego do Acaba Mundo (BORSAGLI, 2016), um claro exemplo dos valores associados a rede hidrográfica urbana. Ao negar a sua preservação e permanência à vista da cidade, foi legado a ela o destino de se tornar receptor e condutor de esgotos e detritos.

Em relação aos transbordamentos de fundo de vale ocorridos após as primeiras intervenções, embasadas pela ideia de erradicação do fenômeno, pode-se concluir que o problema dos transbordamentos se deve pela insistência do ser humano em habitar áreas que não deveriam ser habitadas e modificadas, como as planícies de inundação. No entanto, as sociedades buscam desde a antiguidade intervir nos fenômenos da natureza, na esperança de que um dia alguns dos fenômenos possam ser controlados, ainda que a busca contribua para a sua alteração.

Os limites da microbacia do córrego do Acaba Mundo (Figura 15), ainda que urbanizada e invisibilizada pelo acentuado crescimento do tecido urbano de Belo Horizonte, podem ser parcialmente identificados em diversos trechos à jusante da Avenida Bandeirantes, como nos bairros Sion e Funcionários, visto que as alterações realizadas na paisagem não fizeram desaparecer por completo suas características morfológicas, como partes do antigo fundo de vale no trecho compreendido entre as avenidas Getúlio Vargas e Afonso Pena.

A sociedade interfere e modifica a paisagem de acordo com suas necessidades. Apesar das políticas de diversos centros urbanos na atualidade valorizarem a reinserção dos cursos d'água na paisagem urbana, como um agente concreto que a compõe, a rede hidrográfica coberta de Belo Horizonte, ao que tudo indica, ainda passará décadas sob a cidade e à margem da cidade, até que se adote uma política de reabilitação e reinserção, onde os estudos geográfico-históricos da capital mineira serão prioritários para a elaboração de um plano de reabilitação e reinserção bem-sucedido. 


\section{Sobreposição do leito natural e traçado atual do córrego do Acaba Mundo e afluentes, Belo Horizonte-MG}

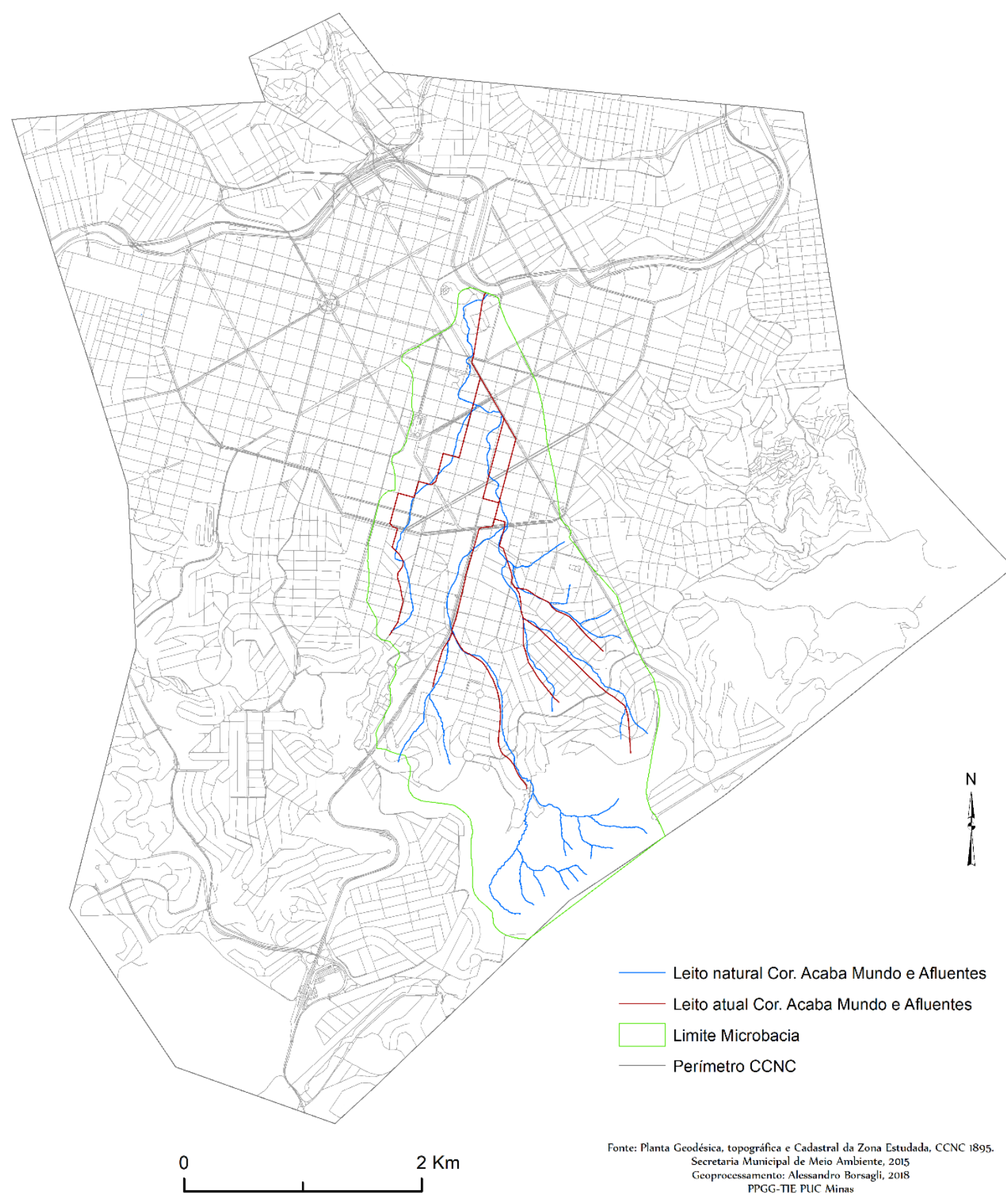

Figura 15 - Sobreposição do leito natural dos cursos d'água integrantes da microbacia do córrego do Acaba Mundo e o traçado atual dos cursos d'água dentro do perímetro delimitado pela CCNC.

Fonte: Elaborado por Borsagli, 2018.

\section{AGRADECIMENTOS}

Os autores agradecem ao PPGG-TIE PUC Minas pelo suporte técnico e ao CNPq pelo suporte financeiro. 


\section{REFERÊNCIAS}

AB'SABER, A. Geomorfologia urbana de São Paulo. São Paulo: Ateliê Editorial, 2007. 349p.

ABREU, M. A. Construindo uma geografia do passado: Rio de Janeiro, cidade portuária, século XVII. Geousp Espaço e Tempo, São Paulo, v. 4, n. 1, p. 13-25, 2000, Universidade de São Paulo, 2000.

, M. A. Geografia Histórica do rio de Janeiro (1502-1700), 2 vols. Rio de Janeiro: Andrea Jakobsson Estúdio \& Prefeitura do Município do Rio de Janeiro, 2010. 420p e 484p.

ANDRADE, W. C. P. O Acaba Mundo já era: o ocultamento dos cursos d'água no centro de Belo Horizonte (1893-1973). 2014. 129 f. Dissertação (Mestrado em Arquitetura e Urbanismo) Universidade Federal de Minas Gerais, Belo Horizonte, 2014.

AGUIAR, T. F. R. Vastos Subúrbios da Nova Capital: formação do espaço urbano na primeira periferia de Belo Horizonte. 2006. 443 f. Tese (Doutorado em História) - Universidade Federal de Minas Gerais, Belo Horizonte, 2006.

BARBOSA, W. A. Dicionário histórico-geográfico de Minas Gerais. Belo Horizonte: Editora Itatiaia, 1981. 382p.

BARRETO, A. Belo Horizonte: memória histórica e descritiva: história antiga. v. 1. Belo Horizonte: Livraria Rex, 1936. 363p.

, A. Belo Horizonte: memória histórica e descritiva: história média. v. 2. Belo Horizonte: Livraria Rex, 1936. 760p.

BELO HORIZONTE. Coleção Relatórios dos Prefeitos 1899-1974. Arquivo Público da Cidade de Belo Horizonte.

BORSAGLI, A. Rios Invisíveis da Metrópole Mineira. Belo Horizonte: Clube de Autores, 2016. 430p.

, A. Sob a sombra do Curral del Rey: contribuições para a história de Belo Horizonte. Belo Horizonte: Clube de Autores, 2017. 452p.

, A. Do convívio a ruptura: a cartografia na análise histórico-fluvial de Belo Horizonte (1894-1977). 2019, 224f. Dissertação (Mestrado em Geografia) - Pontifícia Universidade Católica de Minas Gerais, Belo Horizonte, 2019.

, A. Rios urbanos de Belo Horizonte: geografia histórica da rede hidrográfica da nova capital (1734/2020). Belo Horizonte: Clube de Autores, 2020. 156p.

BOTELHO, R. G. M. Bacias Hidrográficas Urbanas. In: GUERRA, A. J. T. Geomorfologia Urbana. Rio de Janeiro: Bertrand Brasil, 2011.

BURTON, R. F. Viagem do Rio de Janeiro a Morro Velho. Brasília: Senado Federal, 2001. 530p.

CASTElnAU, F. Expedição às regiões centrais da América do Sul. Tomo I. São Paulo: Companhia Editora Nacional, 1949. 383p. 
CASTONGUAY, S.; EVENDEN, M. Urban rivers: remaking rivers, cities and space in Europe and North America. University of Pittsburgh Press, 2010. 256p.

CASTRO, J. F. M. Geoprocessamento de mapas de Minas Gerais nos séculos XVIII e XIX. 1. ed. Belo Horizonte: Editora PUC Minas, 2017. 176p.

COMISSÃO CONSTRUTORA DA NOVA CAPITAL. Revista geral dos trabalhos: publicação periodica, descriptiva e estatistica, feita, com autorisação do governo do estado, sob a autorisação do engenheiro chefe Aarão Reis. Rio de Janeiro, 1895. 148p.

CORRÊA, R. L. Posição geográfica de cidades. Revista Cidades, Presidente Prudente, v. 01, n. 01, p. 317-323, 2004.

DOLLFUS, O. A análise geográfica. São Paulo: Difusão Europeia do Livro, 1973. 121p.

COSTA, L. M. S. A. (Org.). Rios e paisagens urbanas em cidades brasileiras. Rio de Janeiro: Ed. PROURB, 2006. 192p.

DEFFONTAINES, P. Como se constituiu no Brasil a rede de cidades. Bulletin de la Societé de Geographie de Lille, v. 59, n. 9, p. 141-148, 1938.

DELIJAICOV, A. Os rios e o desenho da cidade: proposta de projeto para a orla fluvial da Grande São Paulo. 1998. 112 f. Dissertação (Mestrado em Arquitetura e Urbanismo) - Faculdade de Arquitetura e Urbanismo, Universidade de São Paulo, São Paulo, 1998.

ERTHAL, R. Geografia histórica - considerações. GEOgraphia, Niterói, v. 5, n. 9, p. 29-39, 2003.

ESCHWEGE, W. L. Pluto Brasiliensis. Belo Horizonte: Ed. Itatiaia, 1979. 306p.

FONSECA, M. M. Projeto do Emissário Geral da margem direita do Arrudas. Revista de Engenharia e Arquitetura, n. 16, 1951.

FUNDAÇÃO JOÃO PINHEIRO/Centro de Estudos Históricos e Culturais. Panorama de Belo Horizonte: Atlas Histórico. Belo Horizonte, 1997.

GEIGER, P.; DAVIDOVICH, F. Aspectos do fato urbano no Brasil. Revista Brasileira de Geografia, v. 23, n. 2, p. 263-362, 1961.

GEORGE, P. Geografia Urbana. São Paulo: Difel, 1983. 236p.

GONÇALVES, C. S. A produção de alimentos em Minas Gerais colonial e a fazenda da Borda do Campo. In: ENCONTRO NACIONAL DE HISTÓRIA. 23., 2016, Assis. Anais... Assis, 2016. p. 148-160.

HOYUEla JAYO, J. A. Mapa Histórico Digital de Belo Horizonte. Disponível em: < http://www.mapahistoricodigitalbh.com.br/>. Acesso em: 21 jan. 2020.

JAMES, P. Belo Horizonte e Ouro Preto: estudo comparativo de duas cidades brasileiras. Boletim Geográfico, Rio de Janeiro, v. 4, n. 48, p. 1.598-1.609, 1947. 
LUCHEZI, T. F. O automóvel como símbolo da sociedade contemporânea. In: SEMINÁRIO DE PESQUISA EM TURISMO DO MERCOSUL. 6., 2010. Caxias do Sul. Anais... Caxias do Sul, 2010. p. 1-16.

MESQUITA, Y. M. Jardim de asfalto: água, meio ambiente, canalização e as políticas públicas de saneamento básico em Belo Horizonte, 1948-1973. 2013. 177 f. Dissertação (Mestrado em História) - Universidade Federal de Minas Gerais, Belo Horizonte, 2013.

MARTINS, A. A.; OLIVEIRA, J. M. Almanak administrativo, civil e industrial da Província de Minas Geraes. Rio de Janeiro: Typografia da Actualidade, 1864. 660p.

MINAS GERAES. Commissão d'Estudo das Localidades Indicadas para a nova Capital. Relatório apresentado a S. Ex. Sr. Dr. Affonso Penna, Presidente do Estado, pelo engenheiro civil Aarão Reis. Rio de Janeiro: Imprensa Nacional, 1893. 489p.

NATAL, C. M. Ouro Preto, a construção de uma cidade histórica 1891-1933. 2007. 239 f. Dissertação (Mestrado em História) - Universidade Estadual de Campinas, Campinas, 2007.

PENNA, O. Notas Cronológicas de Belo Horizonte. Belo Horizonte: Fundação João Pinheiro, 1997. $276 \mathrm{p}$.

SAUER, C. Foreword to Historical Geography. Annals of the Association of American Geographers, v. 31, n. 1, p. 1-24, 1941.

SILVA, M. W. A formação de territórios ferroviários no oeste paulista, 1868-1892. 2008. 311 f. Tese (Doutorado em Geografia) - Universidade Federal do Rio de Janeiro, Rio de Janeiro, 2008. 